\title{
REVIEW
}

\section{Pituitary cell type-specific electrical activity, calcium signaling and secretion}

\author{
STANKO S. STOJILKOVIC
}

Section on Cellular Signaling, Endocrinology and Reproduction Research Branch, National Institute of Child Health and Human Development, National Institutes of Health, Bethesda, Maryland, USA.

\begin{abstract}
All secretory anterior pituitary cells exhibit spontaneous and extracellular calcium-dependent electrical activity, but differ with respect to the patterns of firing and associated calcium signaling and hormone secretion. Thus, somatotrophs and lactotrophs fire plateau-bursting action potentials spontaneously and without coupling to calcium release from intracellular stores, which generate calcium signals of sufficient amplitude to keep steady hormone release. In these cells, both spontaneous electrical activity and basal hormone secretion can be further amplified by activation of $\mathrm{G}_{\mathrm{q} / 11}$ and $\mathrm{G}_{\mathrm{s}}$-coupled receptors and inhibited by $\mathrm{G}_{\mathrm{i} / \mathrm{o} / \mathrm{z}}$-coupled receptors. In contrast, gonadotrophs fire single, high-amplitude spikes with limited ability to promote calcium influx and exocytosis, whereas activated $\mathrm{G}_{\mathrm{q} / 11}$-coupled receptors in these cells transform single-action potential spiking into the plateau-bursting type of electrical activity and trigger periodic high-amplitude calcium signals and exocytosis of prestored secretory vesicles. Here, we review biochemical and biophysical aspects of spontaneous and receptorcontrolled electrical activity, calcium signaling, and hormone secretion in pituitary cells.
\end{abstract}

Key terms: somatotrophs, lactotrophs, gonadotrophs, $\mathrm{GH}_{3}$ cells, $\mathrm{SK}$ channels, BK channels, action potentials, exocytosis.

\section{PROLOGUE}

Twenty one years ago in September 1985, I came to the National Institutes of Health as a postdoctoral fellow with ambitions to study biochemical and biophysical properties of pituitary cells. The laboratory of Kevin J. Catt within the National Institute of Child Health and Human Development offered me excellent facilities for the biochemical/molecular biology type of investigations. In a search for collaboration with biophysically oriented laboratory, I asked Greti Aguilera, a Chilean scientist working at that time as a tenured investigator in Endocrinology and Reproduction Research Branch, for advice. She suggested that I approach another Chilean scientist, Eduardo Rojas, who at that time had been working as a principal investigator in the Laboratory of Cell
Biology and Genetics, National Institutes of Diabetes, Digestive and Kidney Diseases.

Eighteen years later, I still remember the excitement that Eduardo's invitation to start preliminary experiments generated within me. When we met for the first time, he immediately asked me why I wanted to study electrical properties of gonadotrophs and gave me several reprints describing the lack of excitability of these cells and their expression of receptor-controlled and voltage-insensitive calcium channels. Although I was not prepared for this or similar questions, he liked my ad hoc rationale for reexamining the issue. Twenty-four hours later, we started experiments. The first clamped gonadotroph exhibited regular spontaneous electrical activity. The second cell showed periodic single channel activity during continuous stimulation with gonadotropin- 
releasing hormone, which several years latter we identified as calcium-activated SK-type potassium channels. By the end of the day, it was obvious that we were embarking on a long-lasting and successful collaboration.

We were pioneers in characterizing many aspects of calcium signaling and calcium-controlled secretion in pituitary cells, including agonist-induced and inositol $(1,4,5)$-trisphophate $\left(\mathrm{InsP}_{3}\right)$ dependent membrane potential and calcium oscillations in gonadotrophs, the role of calcium as coagonist in control of $\mathrm{InsP}_{3^{-}}$ gated calcium channels, the participation of endoplasmic reticulum calcium pump in agonist-induced calcium oscillations, the dependence of agonist-induced calcium oscillations on membrane potential, and the contribution of calcium mobilization and influx in desensitization of voltage-gated calcium channels. During the course of this work, I had a privilege to collaborate with three other brilliant and highly imaginative Chilean scientists working as postdoctoral fellows in Eduardo's laboratory: Andres Stutzin, Manuel Kukuljan, and Leoncio Vergara. My work with Eduardo and his collaborators resulted in the publication of twenty papers in highly prestigious journals.

The publication of this volume of Biological Research dedicated to Professor Eduardo Rojas is a special tribute to a gifted person, an extraordinary scientist, a great colleague, a remarkable teacher, and a wonderful friend. During my postdoctoral studies, Eduardo's warmth, enthusiasm, and friendship reinforced my fascination with biomedical research. When my personal life was in disaster, his encouragements to continue work in science were critical. He was always eager to share the excitement of biomedical investigations and to initiate new projects. I was not only fortunate that I had an opportunity to work with Eduardo and his collaborators for ten years, but also to learn about Chile and its great history of electrophysiological investigations. It is a special pleasure to contribute this reminiscence and a review article that also summarizes many of our experiments done in Bethesda.
SINGLE-SPIKING VS. PLATEAU-BURSTING TYPE OF ELECTRICAL ACTIVITY

The membrane potential $\left(\mathrm{V}_{\mathrm{m}}\right)$ of secretory anterior pituitary cells is not stable but oscillates from the baseline potential of about $-60 \mathrm{mV}$ (Bonnefont and Mollard, 2003). When $V_{m}$ oscillations reach the threshold level, pituitary cells fire action potentials (APs). This is a common feature of all secretory anterior pituitary cells. Although the majority of these cells are derived from the same progenitor cells (Ooi et al., 2004), they differ with respect to the pattern of electrical activity and AP-driven calcium signaling and secretion in vivo and in vitro (Stojilkovic and Catt, 1992; Kwiecien and Hammond, 1998; Stojilkovic et al., 2005). Cultured lactotrophs (Fig. 1A) and somatotrophs (Fig. 1B) frequently exhibit larger $\mathrm{V}_{\mathrm{m}}$ oscillations, on top of which the depolarizing plateau and bursts of APs are generated, with spikes that usually do not reach the reverse potential (Van Goor et al., 2001a; 2001b). Such complex but organized superimposition of APs is termed plateau bursting activity. In contrast, $\mathrm{V}_{\mathrm{m}}$ oscillations in cultured gonadotrophs are small and as yet uncharacterized pacemaker activity generates reverse polarization of $\mathrm{V}_{\mathrm{m}}$ and single APs that are sharp short in duration (Kukuljan et al., 1992; Stojilkovic et al., 1992a). Consequently, they are termed single axonal type APs (Fig. 1D). Immortalized GH pituitary cells can exhibit both single AP spikes (Fig. 1C) and the plateau-bursting pattern of firing (Schlegel et al., 1987; Kwiecien et al., 1998; Giraldez et al., 2002).

Pituitary gonadotrophs also can generate a plateau-bursting type of electrical activity, but only during the activation of $\mathrm{Ca}^{2+}$-mobilizing receptors (Kukuljan et al., 1992; Stojilkovic et al., 1992a; Tse and Hille, 1992). As shown in Fig. 1E, application of gonadotropin-releasing hormone $(\mathrm{GnRH})$ is associated with marked changes in the electrical activity in single gonadotrophs. These include a transitory cessation of spontaneous AP firing, followed by a complex pattern of $\mathrm{V}_{\mathrm{m}}$ oscillations in current-clamped cells. 
Oscillations occur over a frequency range $(5-20 / \mathrm{min})$ that is dependent on agonist concentration. Each cycle of $\mathrm{V}_{\mathrm{m}}$ oscillations is initiated by rapid hyperpolarization, followed by slow depolarization that often leads to the firing of multiple APs (Fig. 1F). Such a pattern of electrical activity resembles the plateaubursting type of $\mathrm{V}_{\mathrm{m}}$ activity in spontaneously active somatotrophs and lactotrophs (Fig. 1E vs. A \& B). At high nanomolar GnRH concentrations, there is rapid and prolonged hyperpolarization of the plasma membrane, followed by sustained oscillations in $\mathrm{V}_{\mathrm{m}}$ (Kukuljan et al., 1992).
PATTERNS OF AP- AND RECEPTOR-CONTROLLED CALCIUM SIGNALS

In general, APs provide an effective mechanism for promotion of extracellular calcium influx and both the frequency and the shape of APs encode the calcium signal. The differences in the patterns of spontaneous firing of APs among secretory pituitary cells are reflected in the pattern of calcium signaling. In spontaneously active gonadotrophs, the high-amplitude, single APs with a duration of milliseconds cause no obvious changes in the intracellular calcium concentrations $\left(\left[\mathrm{Ca}^{2+}\right]_{\mathrm{i}}\right)$ or generate low-amplitude signals ranging from 20 to
A

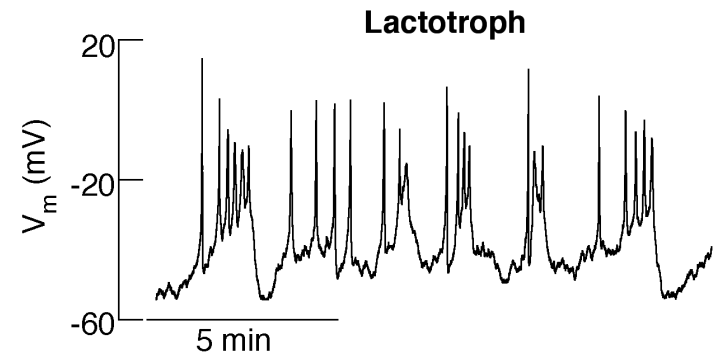

D

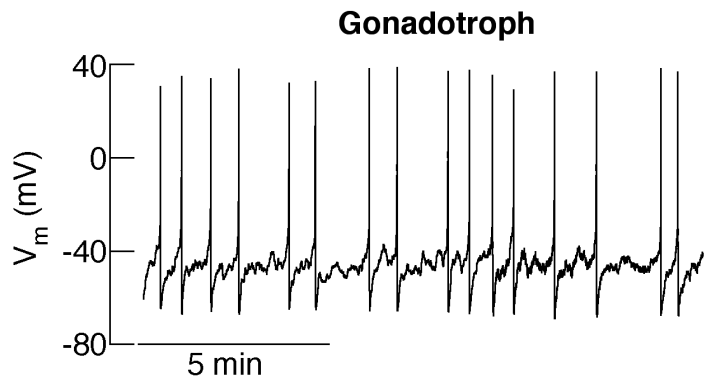

E

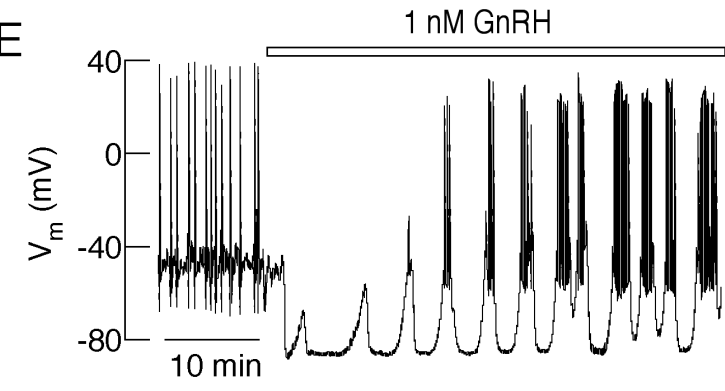

F

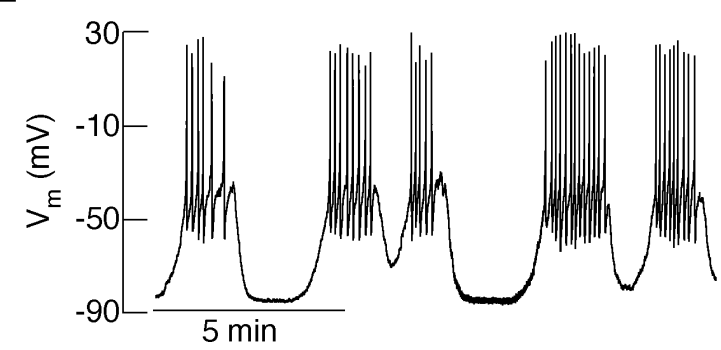

Figure 1. Patterns of spontaneous (A-D) and receptor-controlled (E and F) electrical activity in pituitary cells. GnRH, gonadotropin-releasing hormone. $\mathrm{V}_{\mathrm{m}}$, membrane potential. 
$70 \mathrm{nM}$ (Fig. 2, right). Such APs generate localized $\mathrm{Ca}^{2+}$ signals, just below the plasma membrane, also known as domain calcium (Li et al., 1995; 1997).

Conversely, somatotrophs and lactotrophs generate slow-resting $\mathrm{V}_{\mathrm{m}}$ oscillations with superimposed bursts of APs, with an average duration of seconds and high amplitude that ranges from 0.3 to $1.2 \mu \mathrm{M}$ (Fig. 2, left \& center). The high frequency of single APs in immortalized cells also generates highamplitude $\mathrm{Ca}^{2+}$ signals (Schlegel et al., 1987). These signals are termed global $\mathrm{Ca}^{2+}$ signals because they reflect increase in $\left[\mathrm{Ca}^{2+}\right]_{i}$ in all regions of cells. A line scan mode of confocal imaging shown in Fig. 3 illustrates the global nature of $\mathrm{Ca}^{2+}$ signals in a spontaneously firing somatotroph. Since plateau-bursting APs are periodic in nature, this phenomenon results in oscillatory $\mathrm{Ca}^{2+}$ signaling.
In some cells, APs generate global $\mathrm{Ca}^{2+}$ signals by triggering the release of $\mathrm{Ca}^{2+}$ from the ryanodine-sensitive intracellular stores. This is not the case with normal pituitary somatotrophs and lactotrophs, in which spontaneous $\mathrm{Ca}^{2+}$ transients depend exclusively on $\mathrm{Ca}^{2+}$ influx through plasma membrane channels (Tomic et al., 1999a; Zimber and Simasko, 2000). Also, spontaneous electrical activity (Iida et al., 1991; Van Goor et al., 2001b) in gonadotrophs and short (10-100 ms) depolarization of cell membrane (Vergara et al., 1995) do not trigger $\mathrm{Ca}^{2+}$ release from intracellular stores. Thus, the rise in $\left[\mathrm{Ca}^{2+}\right]_{\mathrm{i}}$ in spontaneously active pituitary cells exclusively depends on voltage-gated $\mathrm{Ca}^{2+}$ influx (VGCI). At the present time, no conclusive evidence was provided for the coupling of VGCI to $\mathrm{Ca}^{2+}$ release in immortalized pituitary cells.

\section{Somatotroph Lactotroph Gonadotroph}
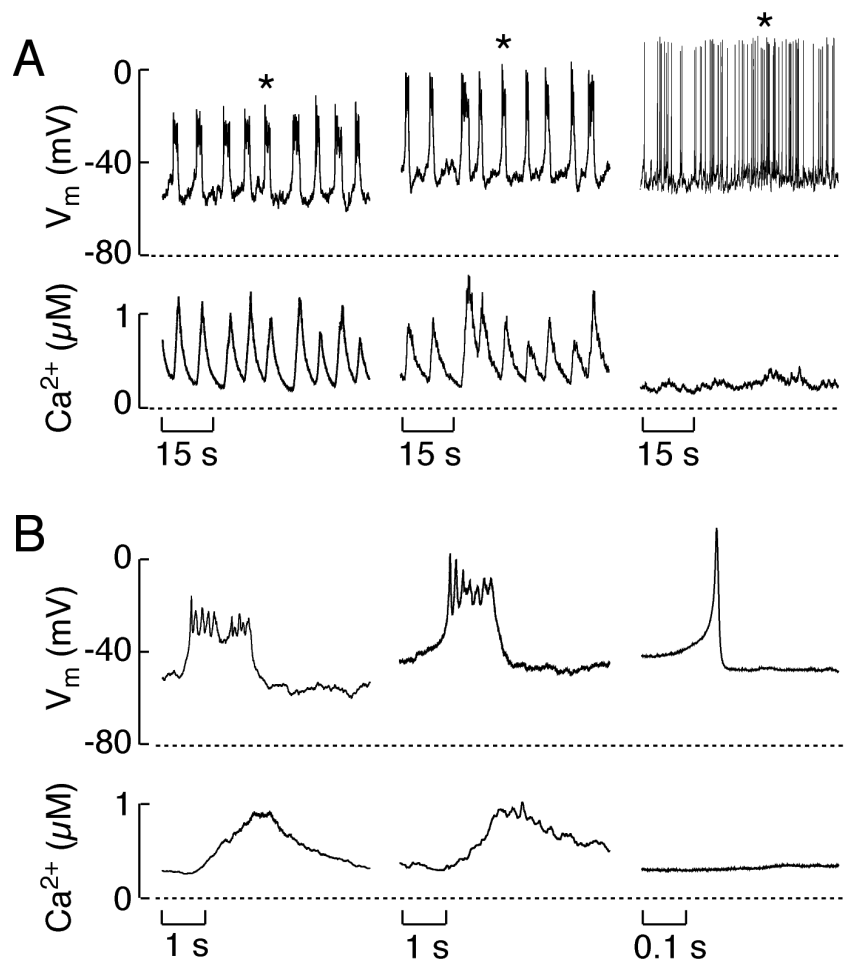

Figure 2. Characterization of spontaneous electrical activity and calcium signaling in cultured pituitary cells. Simultaneous measurements of $\mathrm{V}_{\mathrm{m}}$ and $\left[\mathrm{Ca}^{2+}\right]_{\mathrm{i}}$ in single somatotrophs, lactotrophs, and gonadotrophs. Asterisks in the upper panel illustrate selected APs and corresponding $\mathrm{Ca}^{2+}$ transients, which are shown in the bottom traces on an extended time-scale. Note the difference in time-scale for gonadotrophs. 

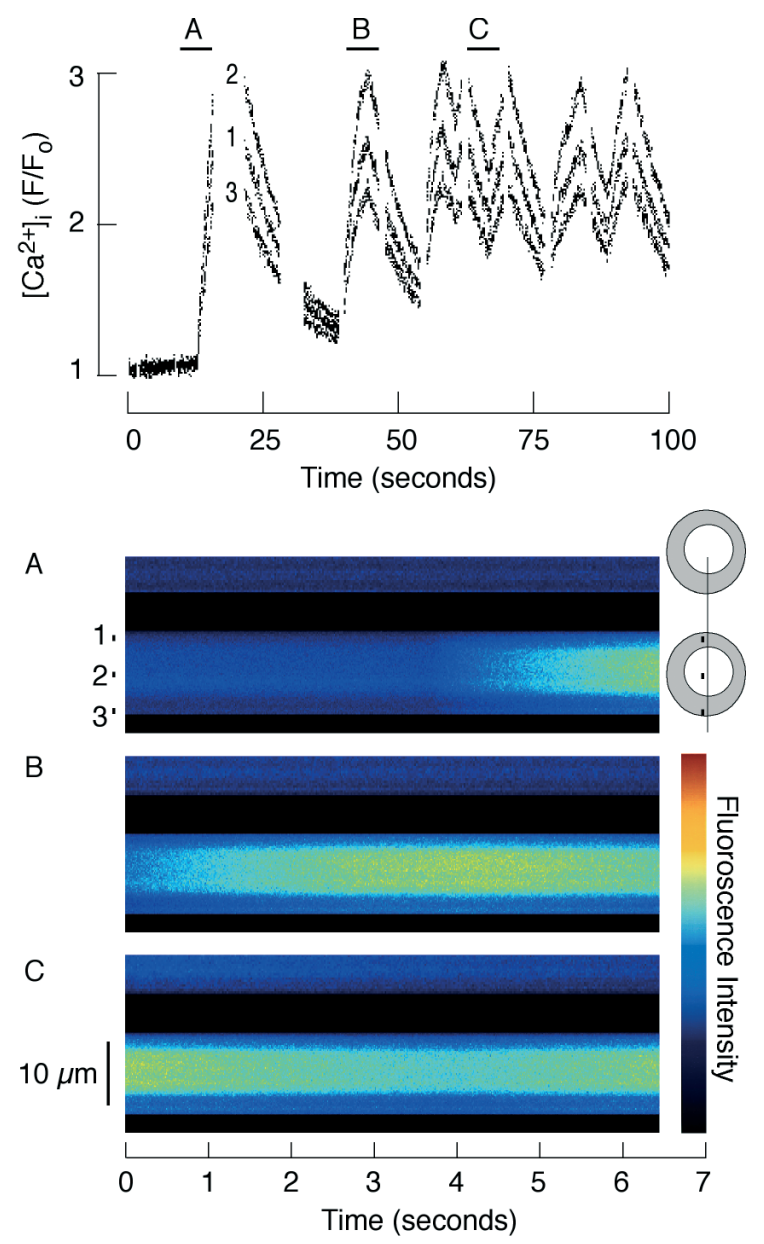

Figure 3. Line scans of a somatotroph in transition from quiescent to active state. As shown in the schematic representation on the right, fluorescence was recorded along a line that passed through a diameter of one cell and partially through another cell. The line was scanned every 6-7 ms during $6.4 \mathrm{~s}$; the XT image was saved and a new series of scans started. Fluorescence intensities were recorded at two line segments positioned in the cytoplasm (labeled as 1 and 3) and one positioned in the nucleoplasm (labeled as 2). Data are presented as ratios between fluorescence intensity at given time and the average baseline intensity for the corresponding line segments. The chosen images show the initiation of a $\left[\mathrm{Ca}^{2+}\right]_{\mathrm{i}}$ transient (A), a period before and after the peak (B), and a fall and subsequent rise in cytosolic and nuclear $\left[\mathrm{Ca}^{2+}\right](\mathrm{C})$. The horizontal lines above the $\left[\mathrm{Ca}^{2+}\right]_{\mathrm{i}}$ profiles indicate the time intervals at which presented XT images were recorded.

Gonadotrophs can generate global oscillatory $\mathrm{Ca}^{2+}$ signals, but only during activation of $\mathrm{Ca}^{2+}$-mobilizing receptors. In parallel to $\mathrm{V}_{\mathrm{m}}$ oscillations (Fig. 4A), application of GnRH in these cells leads to oscillatory changes in current $(B)$ and $\left[\mathrm{Ca}^{2+}\right]_{\mathrm{i}}$ (C). The mean threshold concentration for activation of the base-line oscillatory $\left[\mathrm{Ca}^{2+}\right]_{\mathrm{i}}$ and current responses is about $15 \mathrm{pM}$ for $\mathrm{GnRH}$, and the frequency but not the amplitude of spiking is determined by the agonist concentration (Iida et al., 1991; Stojilkovic et al., 1994; Tomic et al., 1994). The initiation of GnRH-induced $\mathrm{Ca}^{2+} /$ current signaling does not require extracellular $\mathrm{Ca}^{2+}$ and is dependent on release of this ion from the endoplasmic reticulum (ER) (Iida et al., 1991). At elevated GnRH concentrations, the early oscillatory response is replaced by a prolonged spike followed by sustained lowamplitude oscillations, termed biphasic response (Tomic et al., 1994). 

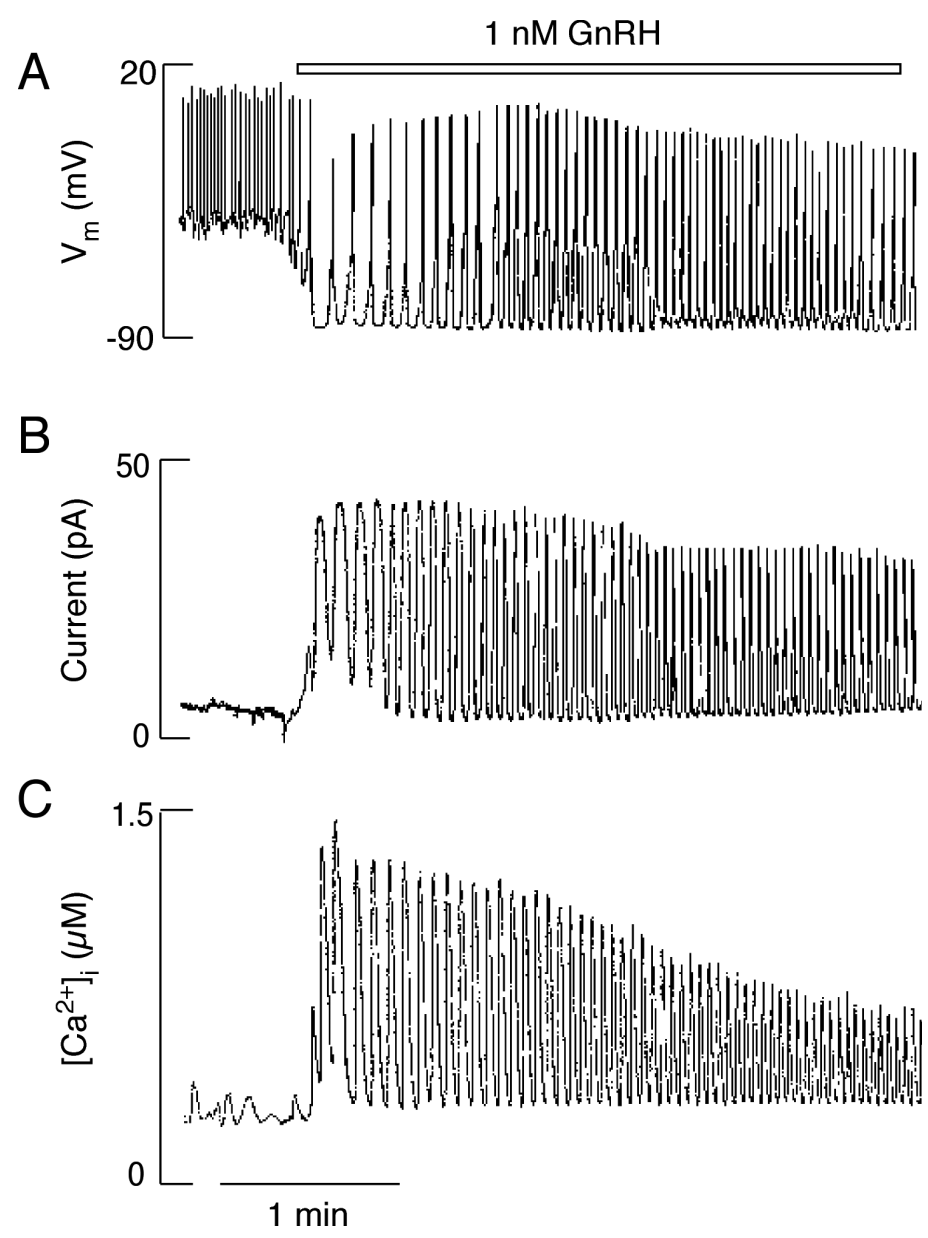

Figure 4. GnRH-induced electrical activity and calcium signaling in gonadotrophs. Activation of GnRH-calcium-mobilizing receptors is associated with baseline $\mathrm{Ca}^{2+}$ oscillations $(\mathrm{C})$ and periodic activation of $\mathrm{Ca}^{2+}$-controlled apamin-sensitive $\mathrm{K}^{+}$channels (B), which transiently hyperpolarize the membrane (A). When $\left[\mathrm{Ca}^{2+}\right]_{i}$ is at baseline levels, apamin-sensitive channels are not activated, and gonadotrophs are able to fire one to five APs. Such a pattern of electrical activity resembles the plateau-bursting type of spontaneous firing in somatotrophs and a fraction of lactotrophs.

It appears that agonist-induced $\mathrm{Ca}^{2+}$ oscillations are unique for gonadotroph subpopulations of anterior pituitary cells. Activation of $\mathrm{Ca}^{2+}$-mobilizing receptors in somatotrophs leads to a transient increase in $\left[\mathrm{Ca}^{2+}\right]_{\mathrm{i}}$, hyperpolarization of cell membrane and abolition of firing, followed by a sustained depolarization of the cell membrane and recovery of firing of APs, usually with higher frequency (Tomic et al., 1999b). A similar pattern of $\mathrm{V}_{\mathrm{m}}$ and $\left[\mathrm{Ca}^{2+}\right]_{\mathrm{i}}$ responses was observed in lactotrophs (Fig. 5A) and immortalized $\mathrm{GH}_{3}$ cells (Fig. 5B). In contrast to $\mathrm{Ca}^{2+}$-mobilizing $\mathrm{TRH}$ receptors, activation of $\mathrm{Ca}^{2+}$ mobilizing endothelin (ET) receptors in somatotrophs (Tomic et al., 1999b) and lactotrophs (Fig. 5B) causes a sustained abolition of electrical activity and associated VGCI. The cross-coupling of ET receptors to pertussis toxin-sensitive $G_{i / o}$ signaling pathway accounts for prolonged inhibition of electrical activity, which is mediated by activation of inward rectifier $\mathrm{K}^{+}$channels (Tomic et al., 2002). Thus, ET receptors generate a unique situation among $\mathrm{Ca}^{2+}$ mobilizing receptors expressed in pituitary cells, as their activation leads to simultaneous depletion of intracellular $\mathrm{Ca}^{2+}$ pools and blockade of $\mathrm{Ca}^{2+}$ influx. 

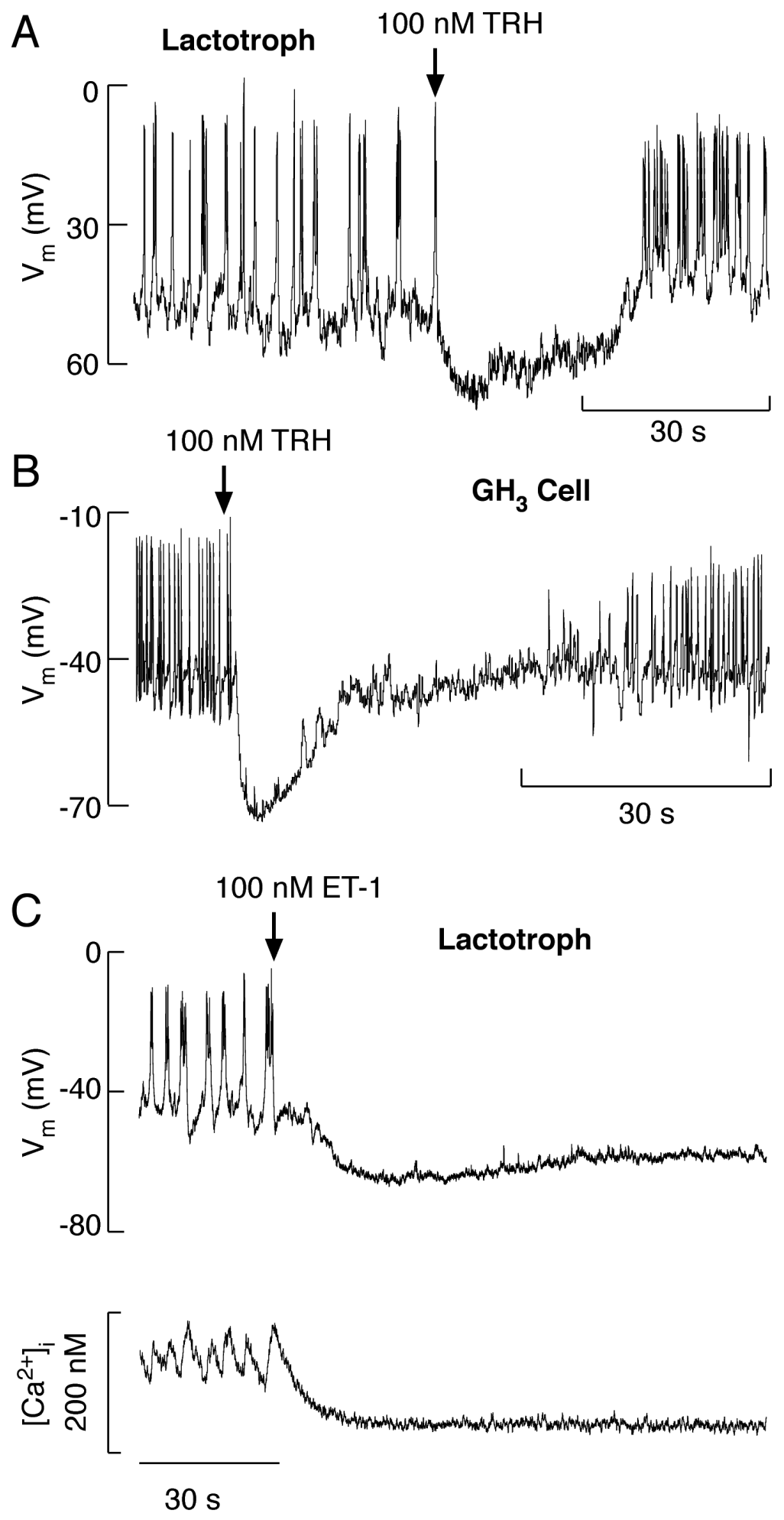

Figure 5. Effects of $\mathrm{Ca}^{2+}$-mobilizing thyrotropin-releasing hormone (TRH) and endothelin-1 (ET-1) on the pattern of electrical activity in spontaneously active lactotrophs $(\mathrm{A} \& \mathrm{C})$ and $\mathrm{GH}_{3}$ cell (B). The transient hyperpolarization was abolished by application of apamin, a specific blocker of SK-type $\mathrm{K}^{+}$channels. Inhibition of SK channels does not change the pattern of actions of TRH and ET-1. 
ROLE OF $\mathrm{CA}^{2+}$-CONTROLLED $\mathrm{K}^{+}$CHANNELS IN PLATEAU-BURSTING TYPE OF ELECTRICAL ACTIVITY

In general, $\mathrm{K}^{+}$channels are key determinants of cellular excitability and are subject to modulation by $\mathrm{Ca}^{2+}$ and other intracellular second messengers. All pituitary cells express slow-inactivating $\mathrm{K}^{+}$ channels at comparable levels, whereas functional expression of the transient $\mathrm{K}^{+}$ channels is much higher in lactotrophs and gonadotrophs than in somatotrophs (Van Goor et al., 2001c). This difference is unlikely to underlie the cell-type-specific firing pattern, because both lactotrophs and somatotrophs exhibit plateau-bursting type of spontaneous electrical activity. The most dramatic differences are related to the expression of $\mathrm{Ca}^{2+}$-activated $\mathrm{BK}$-type $\mathrm{K}^{+}$ channels. The presence of these channels has been shown in immortalized anterior pituitary cells (Ritchie, 1987a; Lang and Ritchie, 1990; Shipston et al., 1996), and native intermediate pituitary cells (Kehl and Wong, 1996). Recent studies indicate that BK channels also are expressed in lactotrophs and somatotrophs and that their activation depends on the status of VGCI (Van Goor et al., 2001c).

As shown in Fig. 6, the two-step protocol applied to cells bathed in $\mathrm{Ca}^{2+}$-containing, and subsequently in $\mathrm{Ca}^{2+}$-deficient, medium indicates the presence of high-amplitude, VGCI-sensitive $\mathrm{K}^{+}$currents in somatotrophs and lactotrophs but not in gonadotrophs. Pharmacological identification of VGCIactivated $\mathrm{K}^{+}$currents is consistent with expression of the BK subtype of these channels in somatotrophs and lactotrophs. First, the specific BK channel blockers, iberiotoxin and paxilline, markedly reduce the $\mathrm{K}^{+}$current in these two cell types. Second, the BK channel activator, NS1619, increases $\mathrm{K}^{+}$current amplitude in somatotrophs and lactotrophs but not in gonadotrophs. Third, unlike the BK channel blockers, the SK channel blocker apamin has no effect on the $\mathrm{K}^{+}$current elicited by the 100 -ms $\mathrm{Ca}^{2+}$-influx step in most of the cells examined (Van Goor et al., 2001c).

In general, the co-localization of $\mathrm{BK}$ channels with voltage-gated calcium channels (VGCCs) facilitates spike repolarization, which limits AP-driven $\mathrm{Ca}^{2+}$ influx (Miranda et al., 2003; Lin et al., 2004). In immortalized pituitary cells, BK channel activation also can influence the frequency of APs by slowing pacemaker depolarization (Haug et al., 2004). On the bases of these results, it would be expected that the relatively high levels of BK channel expression in somatotrophs and lactotrophs should limit AP-driven $\mathrm{Ca}^{2+}$ influx more than in gonadotrophs, which express very few of these channels. However, this hypothesis is inconsistent with the duration of the AP waveforms in the three cell-types. In addition, both the amplitude and duration of the spontaneous, VGCI-dependent $\left[\mathrm{Ca}^{2+}\right]_{\mathrm{i}}$ transients are greater in somatotrophs and lactotrophs than in gonadotrophs. In somatotrophs with buffered $\left[\mathrm{Ca}^{2+}\right]_{i}$, the profile of the AP waveform is shifted from plateau bursting to single spiking. Similar effects also were seen during application of iberiotoxin or paxilline. These, and other results discussed in detail in Van Goor et al. (2001a), indicate that BK channel activation is needed to generate the sustained plateau potential that prolongs AP bursting duration and facilitates extracellular $\mathrm{Ca}^{2+}$ entry in somatotrophs.

The plateau-bursting type of electrical activity observed in GnRH-stimulated gonadotrophs also depends on $\mathrm{Ca}^{2+}$ controlled $\mathrm{K}^{+}$channels, as indicated by the striking similarity in the patterns of $\left[\mathrm{Ca}^{2+}\right]_{i}$ and current $/ \mathrm{V}_{\mathrm{m}}$ oscillations. In accordance with this, simultaneous measurement of both parameters in single gonadotrophs showed that the initial rise in $\left[\mathrm{Ca}^{2+}\right]_{\mathrm{i}}$ is accompanied with hyperpolarization of the membrane, and that the subsequent $\left[\mathrm{Ca}^{2+}\right]_{\mathrm{i}}$ oscillations are in phase with the $\mathrm{V}_{\mathrm{m}}$ oscillations, such that $\left[\mathrm{Ca}^{2+}\right]_{\mathrm{i}}$ peaks correspond to the hyperpolarized phase of the $\mathrm{V}_{\mathrm{m}}$ oscillations (Kukuljan et al., 1992). Apamin, a selective blocker of SK channels, markedly alters the pattern of GnRH-induced current and $V_{m}$ oscillations and shifts the $\mathrm{V}_{\mathrm{m}}$ at the hyperpolarized phase of the oscillations, whereas tetraethylammonium and charybdotoxin are ineffective (Kukuljan et al., 1992; Tse and Hille, 1992). The role of SK channels in generating transient 
hyperpolarization waves also is established in GnRH-stimulated gonadotrophs from neonatal rats (Zemkova and Vanecek, 2000). Experiments with apamin unmasked an additional low-amplitude oscillatory current, which also is activated by the periodic calcium release from the intracellular stores (Vergara et al., 1997). Further experiments are required to clarify the nature of this current.

In contrast to the cell-type-specific expression and coupling of VGCI and BK channel activation, the $\mathrm{SK}$-type of $\mathrm{K}^{+}$ channels in pituitary cells cannot be activated by AP-driven calcium influx. In addition to gonadotrophs, these channels are expressed in other cell types and have a role in agonistcontrolled excitability. For example, the hyperpolarization of cells induced by TRH in lactotrophs and $\mathrm{GH}_{3}$ cells is mediated by SKtype $\mathrm{K}^{+}$channels, whereas the channels responsible for sustained depolarization have not been identified (Sankaranarayanan and Simasko, 1996; Tomic et al., 2003). Together, these findings indicate that SK channels are not active participants in generating oscillatory $\mathrm{Ca}^{2+}$ signals but reflect the status of $\mathrm{Ca}^{2+}$ release from ER.
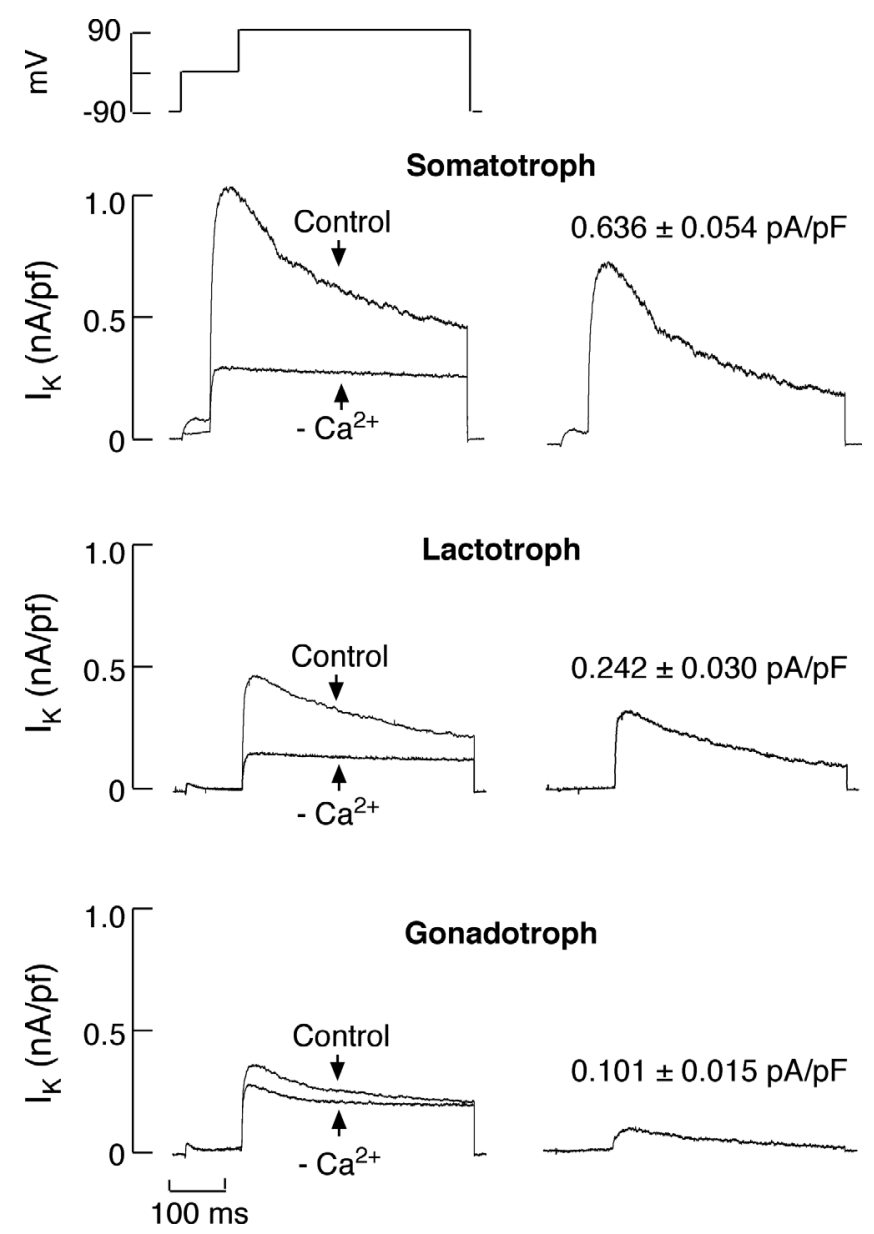

Figure 6. Identification of calcium-activated $\mathrm{K}^{+}$channels in pituitary cells. Left, Representative $\mathrm{K}^{+}$ current traces in somatotrophs, lactotrophs and gonadotrophs evoked by the two step protocol (top panel) in calcium-containing (control) and -deficient medium $\left(-\mathrm{Ca}^{2+}\right)$. The two-step protocol consisted of a $100 \mathrm{~ms}$ condition pulse to $-10 \mathrm{mV}$ to activate voltage-gated $\mathrm{Ca}^{2+}$ influx, followed by a 500-ms test pulse to $90 \mathrm{mV}$, during which the peak $\mathrm{K}^{+}$current was monitored. Right, The net $\mathrm{Ca}^{2+}$-activated $\mathrm{K}^{+}$current activated by the two step protocol was isolated by subtracting the current evoked in the presence and absence of $\mathrm{Ca}^{2+}$. 
DEPENDENCE OF AGONIST-INDUCED CA ${ }^{2+}$ OSCILLATIONS ON PERIODIC CA ${ }^{2+}$ RELEASE THROUGH INSP ${ }_{3}$ CHANNELS

Two lines of evidence indicate that GnRHinduced $\mathrm{Ca}^{2+}$ responses of single gonadotrophs are dependent on increases in $\mathrm{InsP}_{3}$ production. First, agonist-induced $\mathrm{Ca}^{2+}$ oscillations are inhibited by two phospholipase C inhibitors, U73122 and neomycin, in a time- and concentrationdependent manner (Stojilkovic et al., 1994; Zheng et al., 1995). Second, the major patterns of $\mathrm{Ca}^{2+}$ response elicited by intracellular injection of $\mathrm{InsP}_{3}$ are indistinguishable from those induced by GnRH. Each includes a sub-threshold response without oscillations, a thresholdoscillatory response with modulation of spiking frequency by increasing $\operatorname{InsP}_{3}$ concentrations, and a biphasic response with summation of individual spikes into an initial peak followed by a plateau oscillation (Tse and Hille, 1992; Stojilkovic et al., 1993). The mechanism of $\mathrm{Ca}^{2+}$ spiking in pituitary gonadotrophs does not appear to involve fluctuations in $\mathrm{InsP}_{3}$ levels, since cells exposed to its nonhydrolysable analogs show prominent oscillatory responses (Stojilkovic et al., 1993).

The finding that the oscillatory nature of $\mathrm{Ca}^{2+}$ release from intracellular pool is mimicked by non-metabolized forms of $\mathrm{InsP}_{3}$ prompted investigations on the other intracellular factors contributing to the periodic opening and closure of $\mathrm{InsP}_{3}$ receptors. Experiments with isolated $\mathrm{InsP}_{3}$ receptors indicated that $\mathrm{Ca}^{2+}$ acts as a modulator and shifts the channel sensitivity to $\mathrm{InsP}_{3}$ along a bell-shaped curve (Bezprozvanny et al., 1991). Theoretical studies suggested that $\mathrm{Ca}^{2+}$, acting as a coagonist with $\mathrm{InsP}_{3}$ in the control of $\mathrm{Ca}^{2+}$ release from ER, is sufficient to generate oscillations (De Young and Keizer, 1992). Such an action of $\mathrm{Ca}^{2+}$ on $\mathrm{InsP}_{3}$-induced $\mathrm{Ca}^{2+}$ release is a key feature in the operation of the ER oscillator, a process described by Lechleiter and Clapham (1992) and Keizer et al. (1995) as intracellular calcium excitability, i.e., ER calcium excitability. In accord with this, changes in $\left[\mathrm{Ca}^{2+}\right]_{i}$ produced by overexpressing ER $\mathrm{Ca}^{2+}$ pump (Camacho and Lechleiter, 1993) and by stimulation and inhibition of $\mathrm{Ca}^{2+}$ entry through voltageinsensitive (Girard and Clapham, 1993) and voltage-sensitive $\mathrm{Ca}^{2+}$ channels (Kukuljan et al., 1994) were found to modulate the frequency of spiking.

In general, de Young and Keizer's model of $\mathrm{InsP}_{3}$-controlled model of $\mathrm{Ca}^{2+}$ oscillations is based on sequential positive and negative effects of this cation on $\mathrm{InsP}_{3}$ receptors and is adequate to accommodate the temporal and spatial nature of agonistinduced intracellular $\mathrm{Ca}^{2+}$ signaling in gonadotrophs. The details of the bidirectional effects of $\mathrm{Ca}^{2+}$ on $\mathrm{InsP}_{3}$ receptor-channels in these cells were provided in elegant experiments by Rojas' group (Vergara et al., 1995). The ability of a membrane depolarization pulse to reset the phase of ER-derived $\mathrm{Ca}^{2+}$ oscillations strongly supports the hypothesis that $\mathrm{Ca}^{2+}$ exerts a stimulatory effect on $\mathrm{Ca}^{2+}$ release from the ER. The time needed to induce such phase resetting ranges between 50 and $100 \mathrm{~s}$. On the other hand, the use of a double-pulse protocol, with variation in the time between depolarization pulses, revealed that gonadotrophs need time to undergo the slow transition after the previous spike before they could again be activated by $\mathrm{Ca}^{2+}$. This time was estimated to be about $1.2 \mathrm{~s}$, which is consistent with the duration of refractoriness of the $\mathrm{InsP}_{3}$ receptor channels (Vergara et al., 1995).

Agonist-induced $\mathrm{Ca}^{2+}$ release in other anterior pituitary cells also is dependent on production of $\mathrm{InsP}_{3}$ and subsequent activation of $\mathrm{Ins}_{3}$ receptors. At the present time, however, it is not clear why $\mathrm{Ca}^{2+}$ release in gonadotrophs but not in other pituitary cells types is periodic. We may speculate that the expression of different subtypes of $\operatorname{Ins}_{3}$ receptors among pituitary cells alters the co-agonist action of $\mathrm{Ca}^{2+}$ required for oscillatory nature of $\mathrm{Ca}^{2+}$ release. It also is possible that the intracellular organization of the ER structure differs among the subpopulations of pituitary cells, which in turn may influence the spatial aspect of signaling. 
ROLE OF ER CA ${ }^{2+}$ PUMP IN INSP $_{3}$-DEPENDENT CA ${ }^{2+}$ OSCILLATIONS

The importance of $\left(\mathrm{Ca}^{2+}\right)$ ATPase in $\mathrm{InsP}_{3^{-}}$ induced $\mathrm{Ca}^{2+}$ oscillations was demonstrated in experiments with thapsigargin and 2,5di-(tert-butyl)-1,4-benzohydroquinone, which act as specific blockers of the ER $\mathrm{Ca}^{2+}$ pump (Iida et al., 1991; Stojilkovic et al., 1994; Tse et al., 1994a). The application of these blockers in oscillatory cells leads to the cessation of $\mathrm{Ca}^{2+}$ spiking. The sustained and extracellular $\mathrm{Ca}^{2+}$ dependent $\mathrm{Ca}^{2+}$ and $\mathrm{V}_{\mathrm{m}}$ oscillations also are abolished by application of thapsigargin (Stojilkovic et al., 1992a; Kukuljan et al., 1994). These effects are consistent with the view that the ER $\mathrm{Ca}^{2+}$ pump is an integral element of the $\mathrm{InsP}_{3}$ and $\mathrm{Ca}^{2+}$-controlled oscillatory response; $\left(\mathrm{Ca}^{2+}\right)$ ATPase overcomes the negative effect of $\left[\mathrm{Ca}^{2+}\right]_{i}$ on its own release by pumping the ion into the ER and thereby favoring re-initiation of the $\mathrm{Ca}^{2+}$ response (Keizer et al., 1995). Thus, during GnRH stimulation, the intracellular $\mathrm{Ca}^{2+}$ pools discharge their ion contents into the cytoplasm and subsequently reaccumulate $\mathrm{Ca}^{2+}$ from that source, including $\mathrm{Ca}^{2+}$ entering through VGCCs.

\section{ROLE OF MITOCHONDRIA IN CALCIUM SIGNALING}

Among the secretory anterior pituitary cells, the role of mitochondria in $\mathrm{Ca}^{2+}$ signaling was studied only in agonist-stimulated gonadotrophs. Initially, it was suggested that GnRH-stimulated gonadotrophs operate as "closed" cells (i.e., with no extrusion of calcium) and that the re-uptake and release of $\mathrm{Ca}^{2+}$ from mitochondria participates in intracellular calcium homeostasis (Tse et al., 1994b). In further studies using $\mathrm{Ca}^{2+}$ green-1 and rhod-2 as optical measures of cytoplasmic and mitochondrial free $\mathrm{Ca}^{2+}$, the same group showed that mitochondria sequester $\mathrm{Ca}^{2+}$ and tune the frequency of $\mathrm{Ca}^{2+}$ oscillations but, in contrast to the blockade of ER $\mathrm{Ca}^{2+}$ pump, do not abolished oscillatory response. Hille's group also showed that mitochondria lower the localized $\mathrm{Ca}^{2+}$ near sites that trigger exocytosis (Kaftan et al., 2000).
Consistent with the participation of mitochondria in $\mathrm{Ca}^{2+}$ homeostasis, during repetitive GnRH stimulation of short duration, removal of $\mathrm{Ca}^{2+}$ had only a minor effect on baseline oscillations but abolished spike response, whereas removal of $\mathrm{Na}^{+}$ slightly extended duration of baseline oscillations and considerably prolonged spike responses (Zemkova et al., 2004). Taken together, these results indicate that two $\mathrm{Ca}^{2+}$ handling mechanisms are operative in gonadotrophs: redistribution of $\mathrm{Ca}^{2+}$ within ER and mitochondrial pools and a $\mathrm{Na}^{+}$-dependent $\mathrm{Ca}^{2+}$ efflux followed by $\mathrm{Ca}^{2+}$ influx. Redistribution of $\mathrm{Ca}^{2+}$ within the cell leads to a rapid recovery of Ins $\mathrm{P}_{3}$-dependent pool, whereas the $\mathrm{Na}^{+}$dependent $\mathrm{Ca}^{2+}$ efflux pathway is activated by spike response and limits the time of exposure to elevated $\left[\mathrm{Ca}^{2+}\right]_{\mathrm{i}}$.

DEPENDENCE OF INSP ${ }_{3}$-CONTROLLED CA ${ }^{2+}$ OSCILLATIONS ON VGCI IN GONADOTROPHS

Redistribution of $\mathrm{Ca}^{2+}$ between ER and mitochondria does not protect the depletion of intracellular $\mathrm{Ca}^{2+}$ pools during sustained oscillations. Both GnRH- and $\mathrm{InsP}_{3}$ induced current oscillations are extinguished by hyperpolarization after 10 15 min despite the availability of $\mathrm{Ca}^{2+}$ in the extracellular medium (Stojilkovic et al., 1992a). In such treated cells, application of short, depolarizing pulses transiently restores the dihydropyridine-sensitive and extracellular $\mathrm{Ca}^{2+}$-dependent current oscillations, clearly indicating the relevance of VGCI in sustained $\mathrm{Ca}^{2+}$ signaling (Kukuljan et al., 1994). Such responses to depolarization show a marked dependence on $\mathrm{V}_{\mathrm{m}}$ with a midpoint of $-15 \mathrm{mV}$ and sensitivity to dihydropyridines, consistent with the involvement of L-type VGCCs in the function of the ER oscillator. Furthermore, reduction of extracellular $\mathrm{Ca}^{2+}$ by EGTA and blockade of VGCCs abolishes both $\left[\mathrm{Ca}^{2+}\right]_{\mathrm{i}}$ and sustained $\mathrm{V}_{\mathrm{m}}$ oscillations in GnRH-stimulated gonadotrophs (Kukuljan et al., 1997). Finally, repetitive application of brief, depolarizing pulses modulates the frequency of agonist- and $\mathrm{InsP}_{3}$-induced 
spiking. Depolarizing pulses applied at frequencies lower than the intrinsic rate of episodic $\mathrm{Ca}^{2+}$ release trigger large transients between the autonomous spikes, while higher frequencies of depolarizing pulses overcame the original $\mathrm{Ca}^{2+}$ spiking frequency (Kukuljan et al., 1994; 1997). These findings indicate that VGCI facilitates its liberation from intracellular stores by a direct and instantaneous action on the release mechanism. It also sustains spiking, but does not protect the gradual depletion of intracellular $\mathrm{Ca}^{2+}$ stores during sustained receptor activation. However, VGCI is critical for refilling of the ER $\mathrm{Ca}^{2+}$ stores after washout of agonist (Li et al., 1997).

SPONTANEOUS EXCITABILITY AND BASAL HORMONE SECRETION

Calcium is the primary intracellular signaling molecule controlling the fusion of secretory vesicles with the plasma membrane to release transmitters from neurons and hormones from endocrine cells (Martin, 2003). This process is termed regulated exocytosis, and is mediated by complex protein machinery that is conserved in organisms ranging from yeast to mammals. These proteins participate in docking, ATP-dependent priming, and fusion of vesicle membranes through interactions that are still not fully characterized (Rettig and Neher, 2002; An and Almers, 2004; Di Paolo et al., 2004). In regulated exocytosis, an increase in $\left[\mathrm{Ca}^{2+}\right]_{\mathrm{i}}$ is required for two steps: priming the secretory vesicles, which occurs on the time-scale of tens of seconds, and triggering the fusion, which occurs within 1-2 s (Martin, 2003). The priming process requires 10 to 40 seconds.

Excitable cells secrete in a regulated manner through AP-driven $\mathrm{Ca}^{2+}$ influx and $\mathrm{Ca}^{2+}$-dependent exocytosis. The strength of $\mathrm{Ca}^{2+}$ secretion coupling depends on the pattern of $\mathrm{Ca}^{2+}$ signals and cell types, i.e., there are some differences in molecular mechanisms underlying exocytosis and recapture of synaptic and secretory vesicles (Tsuboi et al., 2004). At synapses, the domain $\mathrm{Ca}^{2+}$ triggered by a single $\mathrm{AP}$ is sufficient to activate secretion of vesicles because the predocked release-ready vesicles are linked molecularly to $\mathrm{Ca}^{2+}$ channels localized in active zones, which facilitates their rapid release in response to single APs (Rettig and Neher, 2002). Conversely, the distance between secretory vesicles and $\mathrm{Ca}^{2+}$ channels in pituitary cells is large and domain $\mathrm{Ca}^{2+}$ cannot reach the secretory vesicles. For example, in rat melanotrophs, a short depolarization evokes only a minor degree of secretion (Mansvelder and Kits, 1998). Basal electrical activity (Van Goor et al., 2001b) and short depolarization steps in single gonadotrophs (Tse et al., 1997) also are insufficient to stimulate exocytosis, in contrast to the action of high-amplitude, agonist-induced $\mathrm{Ca}^{2+}$ oscillations (Tse et al., 1993), indicating that in this cell type, global $\mathrm{Ca}^{2+}$ signals are required to trigger secretion.

Consistent with these findings, basal (in the absence of agonists, also termed intrinsic or spontaneous) prolactin (PRL) and growth hormone $(\mathrm{GH})$ secretion is high and occurs in an extracellular $\mathrm{Ca}^{2+}$ dependent manner (Ben-Jonathan and Hnasko, 2001). The relationship between the pattern of spontaneous $\mathrm{Ca}^{2+}$ signaling and basal hormone secretion is illustrated in Fig. 7. Basal GH and PRL release is high and is abolished by removal of extracellular $\mathrm{Ca}^{2+}$, a treatment that also abolishes spontaneous electrical activity and highamplitude $\mathrm{Ca}^{2+}$ transients. In contrast, basal gonadotropin release is low, at the level of detection by radioimmunoassay, and is not affected by blockade of electrical activity and VGCI (Van Goor et al., 2001b), confirming that the global but not the domain $\mathrm{Ca}^{2+}$ signals in spontaneously firing pituitary cells are able to trigger secretion.

ROLE OF DEPOLARIZING VOLTAGE-GATED CHANNELS IN CALCIUM SIGNALING AND SECRETION

In general, differences in the expression levels of ionic channels should underlie the cell-type specific patterns of APs, VGCI, 
and hormone secretion. Earlier studies provided evidence that pituitary cells express numerous plasma membrane channels, including tetrodotoxin (TTX)sensitive $\mathrm{Na}^{+}$channels, VGCCs, transient and delayed rectifying $\mathrm{K}^{+}$channels, and multiple $\mathrm{Ca}^{2+}$-sensitive $\mathrm{K}^{+}$channel subtypes (Ritchie, 1987b; Mason and Rawlings, 1988; Korn et al., 1991; Kukuljan et al., 1992; Mollard et al., 1994; Sankaranarayanan and Simasko, 1996; Kwiecien and Hammond, 1998). There are some quantitative differences in the level of expression of TTX-sensitive channels among anterior pituitary cells; under identical culture and recording conditions, lactotrophs and somatotrophs exhibit lower expression levels of TTX-sensitive $\mathrm{Na}^{+}$ channels than do gonadotrophs. These channels are not critical for firing of APs and hormone secretion, as indicated by the lack of effects of TTX on patterns of spontaneous electrical activity and basal hormone release in lactotrophs and somatotrophs (Van Goor et al., 2001b). In gonadotrophs, TTX also does not influence spontaneous firing of APs, but in $\mathrm{GnRH}-$ stimulated cells these channels are responsible for re-initiation of firing during the hyperpolarized phase.

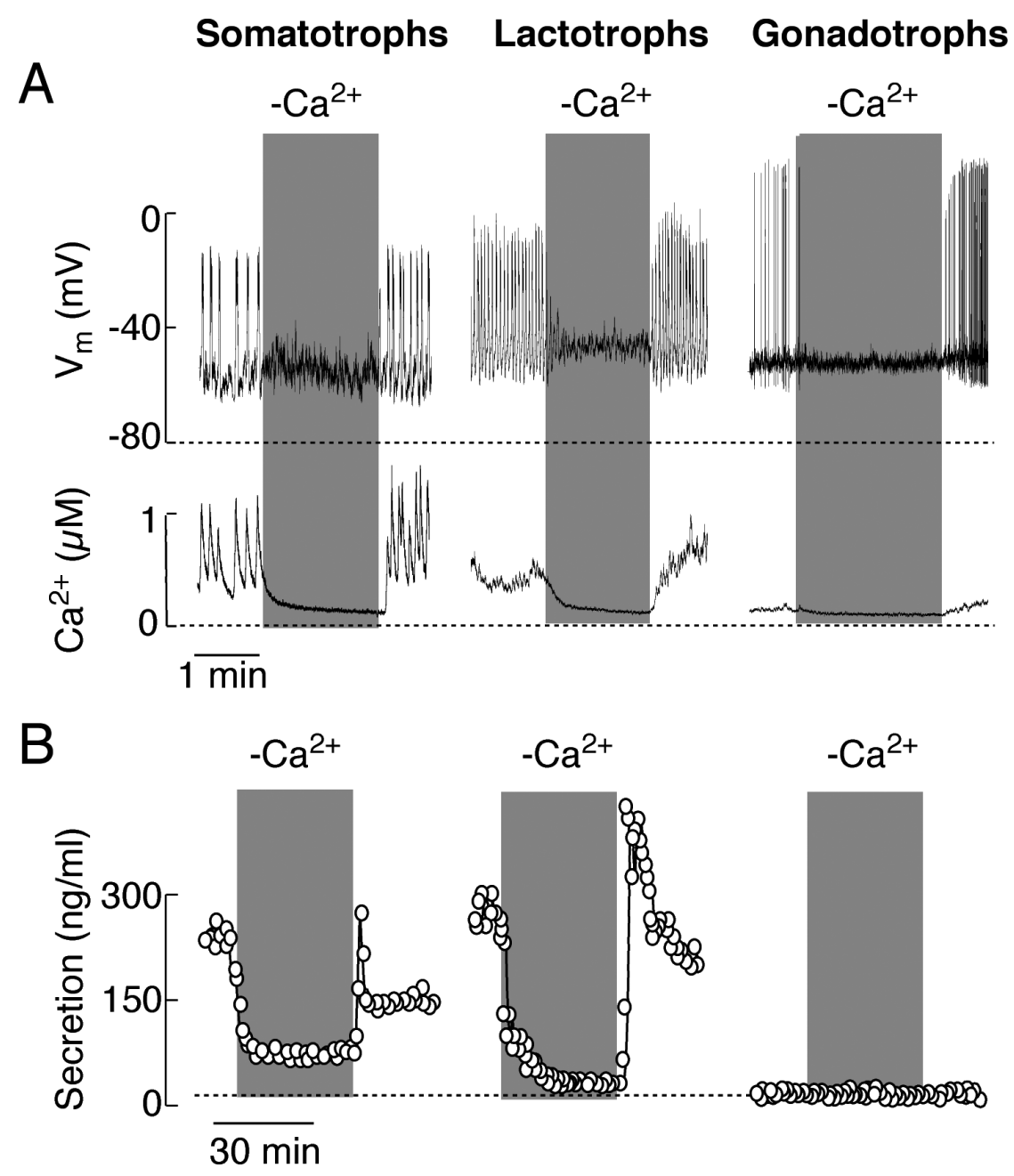

Figure 7. Extracellular calcium dependence of spontaneous electrical activity, calcium signaling, and basal PRL release. A, Effects of removal of extracellular $\mathrm{Ca}^{2+}$ on spontaneous $\mathrm{V}_{\mathrm{m}}$ oscillations and $\left[\mathrm{Ca}^{2+}\right]_{\mathrm{i}}$ transients. B, Effects of removal of extracellular $\mathrm{Ca}^{2+}$ on basal GH (left panel), PRL (central panel), and gonadotropin (right panel) release. 
Both inactivating and non-inactivating VGCCs are found in rat gonadotrophs (Stutzin et al., 1989; Tse and Hille, 1993), somatotrophs and lactotrophs (Lewis et al., 1988), as well as immortalized pituitary cells (Dubinsky and Oxford, 1984; Simasko et al., 1988; Kwiecien et al., 1998). The inactivating $\mathrm{Ca}^{2+}$ current is mediated by the low-voltage activated or transient (T)-type VGCCs, and the non-inactivating $\mathrm{Ca}^{2+}$ channels is mediated by dihydropyridinesensitive (L-type) and dihydropyridineinsensitive, high-voltage activated VGCCs (Stutzin et al., 1989; Tse and Hille, 1993; Kwiecien et al., 1998). Comparative studies with three cell types indicate that T-type current is more prominent in somatotrophs than in lactotrophs and gonadotrophs (Van Goor et al., 2001c). In spontaneously active somatotrophs, these channels contribute to the pacemaking activity (Tomic et al., 1999a). They also may play a pacemaking role in gonadotrophs ( $\mathrm{Li}$ et al., 1995). Ltype VGCCs are expressed in all secretory anterior pituitary cells. The current-voltage relationship of L-type current in all three cell-types is similar, but the current density is higher in somatotrophs and gonadotrophs than in lactotrophs. The critical importance of these channels in spontaneous electrical activity and basal GH and PRL release is illustrated in experiments with pituitary cells during transient blockade of these channels with nifedipine and $\mathrm{Cd}^{2+}$ (Van Goor et al., 2001b). In gonadotrophs, these channels undergo $\mathrm{Ca}^{2+}$-dependent inactivation; both VGCI (Stojilkovic et al., 1990a) and receptor-controlled $\mathrm{Ca}^{2+}$ release from intracellular stores (Stojilkovic et al., 1989) participate in desensitization of Ltype channels.

The pattern of electrical activity (plateau bursting vs. single spiking) rather than the level of expression of VGCCs is the major factor determining cell-type specific pattern of secretion. As shown in Fig. 8, the peak amplitude in $\left[\mathrm{Ca}^{2+}\right]_{i}$ increases progressively with lengthening duration of the depolarizing $\mathrm{V}_{\mathrm{m}}$ steps in all three celltypes. Furthermore, gonadotrophs, lactotrophs, and somatotrophs exhibit comparable $\left[\mathrm{Ca}^{2+}\right]_{i}$ and secretory responses during steady-state depolarization of cells with $50 \mathrm{mM} \mathrm{K}^{+}$, indicating that the secretory vesicles in gonadotrophs also respond to high-amplitude VGCI signals. Finally, a shift in the firing pattern of gonadotrophs from single-spiking to plateau-bursting AP induced by Bay $\mathrm{K}$ 8644, an L-type $\mathrm{Ca}^{2+}$ channel activator, is sufficient to trigger gonadotropin secretion when accompanied by increased frequency of firing (Van Goor et al., 2001b). It is possible that an increase in the frequency of firing, without changing the pattern of APs, also would be sufficient to generate global $\mathrm{Ca}^{2+}$ signals and trigger secretion, but this relation has not yet been studied in gonadotrophs.

\section{A}

B
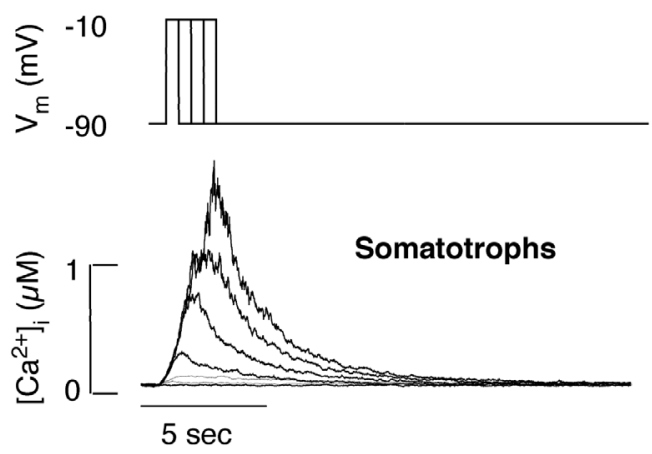

C
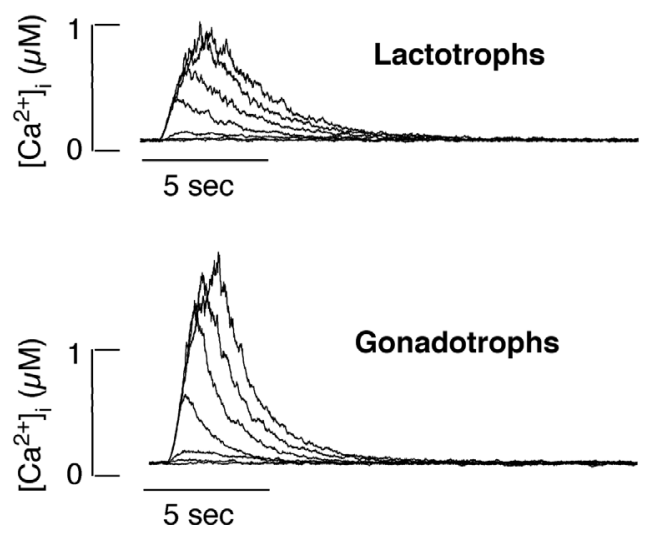

Figure 8. Depolarization-induced rise in $\left[\mathrm{Ca}^{2+}\right]_{\mathrm{i}}$ in pituitary cells. A, Cells were clamped at -90 $\mathrm{mV}$ and transiently ( $25 \mathrm{~ms}$ to $2 \mathrm{~s}$ ) depolarized to $10 \mathrm{mV}$. B-D, Typical profiles of $\left[\mathrm{Ca}^{2+}\right]_{\mathrm{i}}$ responses to depolarizing pulses of variable duration in somatotrophs (B), lactotrophs (C), and gonadotrophs (D). 
PARTICIPATION OF DEPOLARIZING ATP-GATED P2X CHANNELS IN $\mathrm{CA}^{2+}$ SIGNALING AND SECRETION

Several lines of evidence also indicate that an extracellular nucleotide-controlled signaling system is expressed and operative in anterior pituitary cells and may participate in control of pacemaking activity and basal hormone secretion. First, ATP is co-stored with hormones in secretory vesicles and co-secreted by anterior pituitary cells (Chen et al., 1995; Tomic et al., 1996; He et al., 2005). Second, ATP-gated P2X receptor-channels are expressed in these cells (Stojilkovic and Koshimizu, 2001; Rees et al., 2003). To date, seven functional ATP-gated P2X receptor-channels $\left(\mathrm{P} 2 \mathrm{X}_{1}\right.$ to $\left.\mathrm{P} 2 \mathrm{X}_{7}\right)$ have been identified in mammals (North, 2002). Molecular cloning and functional characterization of rat $\mathrm{P} 2 \mathrm{X}$ channels in the pituitary revealed the expression of several subtypes. Initially, the mRNA messages for $\mathrm{P} 2 \mathrm{X}_{2 \mathrm{a}}$ receptors and its spliced form, $\mathrm{P} 2 \mathrm{X}_{2 \mathrm{~b}}$, were identified in pituitary cells (Brake et al., 1994; Koshimizu et al., 1998a; Koshimizu et al., 1998b). Further investigations revealed the expression of mRNA transcripts for $\mathrm{P}_{2} \mathrm{X}_{3}, \mathrm{P} 2 \mathrm{X}_{4}$ and $\mathrm{P} 2 \mathrm{X}_{7}$ receptors in these cells (Koshimizu et al., 2000). Functional $\mathrm{P}_{2} \mathrm{X}_{4}$ receptors are expressed in lactotrophs and contribute to ATP-induced PRL release (He et al., 2003),

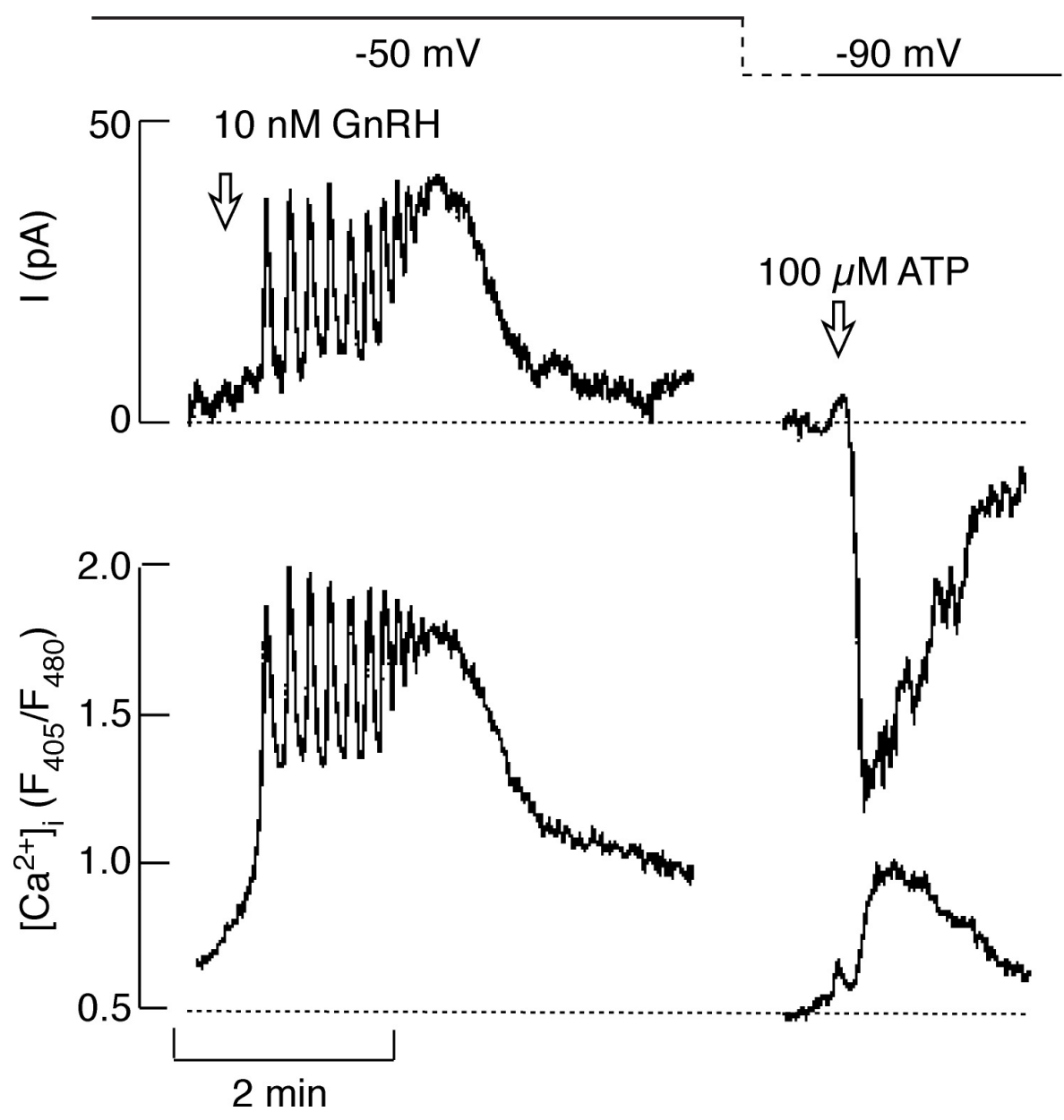

Figure 9. Identification of ATP-gated calcium-conducting P2X channels in gonadotrophs simultaneous $\mathrm{V}_{\mathrm{m}}$ and $\left[\mathrm{Ca}^{2+}\right]_{\mathrm{i}}$ measurements. In a patch-clamped gonadotroph identified by prior treatment with GnRH, ATP induced an inward depolarizing current and rise in $\left[\mathrm{Ca}^{2+}\right]_{\mathrm{i}}$. The participation of VGCI was excluded by clamping the cell at $-90 \mathrm{mV}$. 
whereas $\mathrm{P} 2 \mathrm{X}_{2}$ receptors play a major role in control of gonadotropin release (Tomic et al., 1996; Zemkova et al., 2006). As shown in Fig. 9, in identified gonadotrophs ATP induced an inward depolarizing current of about $50 \mathrm{pA}$, which was accompanied with a significant increase in $\left[\mathrm{Ca}^{2+}\right]_{\mathrm{i}}$. In this particular experiment, the role of VGCI was excluded by clamping the cell to $-90 \mathrm{mV}$ (Tomic et al., 1996). The autocrine/ paracrine actions of ATP are controlled by ectonucleotidases, a family of enzymes that also are expressed in pituitary cells (Tomic et al., 1996; He et al., 2005). These enzymes degrade extracellular ATP in a sequential manner to adenosine (Zimmermann, 2000).

\section{RECEPTOR-CONTROLLED CA ${ }^{2+}$ SIGNALING AND SECRETION}

The intracellular messenger cascades involving $\mathrm{G}$ proteins (Cabrera-Vera et al., 2003) have prominent effects on secretion, predominantly by modulating VGCI and $\mathrm{Ca}^{2+}$ mobilization (Stojilkovic and Catt, 1995; Ashworth and Hinkle, 1996; BluetPajot et al., 1998; Freeman et al., 2000; BenJonathan and Hnasko, 2001). Consistent with the pattern of spontaneous GH and PRL secretion, in vivo lactotrophs and somatotrophs are under tonic-negative hypothalamic control by $\mathrm{G}_{\mathrm{i} / \mathrm{o}}$-coupled dopamine and somatostatin receptors. These receptors inhibit spontaneous electrical activity and VGCI (Mayo et al., 1995; Freeman et al., 2000; Ben-Jonathan and Hnasko, 2001; Sun et al., 2003). Conversely, the physiological control of gonadotropin secretion from the anterior pituitary gland depends on the pulsatile delivery of GnRH from the hypothalamus (Krsmanovic et al., 1996). Hille's group observed periodic exocytosis in GnRH-stimulated single gonadotrophs (Tse et al., 1993). In their experiments, simultaneous measurements of $\left[\mathrm{Ca}^{2+}\right]_{\mathrm{i}}$ and exocytosis showed that each $\mathrm{Ca}^{2+}$ spike induces a burst of exocytosis. These phenomena were suppressed in cells by buffering intracellular $\mathrm{Ca}^{2+}$ but persisted in the absence of extracellular $\mathrm{Ca}^{2+}$. In an additional study, the authors showed that strong exocytosis requires high $\left[\mathrm{Ca}^{2+}\right]_{\mathrm{i}}$, with half maximal concentration of $16 \mu \mathrm{M}$. For early exocytosis, Ins $\mathrm{P}_{3}$-dependent $\mathrm{Ca}^{2+}$ release is sufficient to fully mimic the action of $\mathrm{GnRH}$, suggesting that other messengers are not required (Tse et al., 1997).

CONTRIBUTION OF OTHER INTRACELLULAR MESSENGERS IN CONTROL OF EXOCYTOSIS

The intracellular messengers triggered by G-protein-coupled receptors, including cAMP/protein kinase A (Sakaba and Neher, 2003; Nagy et al., 2004), diacylglycerol/ protein kinase C (Gillis et al., 1996; Yang et al., 2002), and $\mathrm{PIP}_{2} / \mathrm{PI} 3$-kinase (Di Paolo et al., 2004; Grishanin et al., 2004), also can influence $\mathrm{Ca}^{2+}$-triggered secretion by regulating the size of the releasable secretory pool and the rate of exocytosis. Furthermore, it has been suggested that $G$ proteins may inhibit synaptic transmission in neuromuscular junction downstream of $\mathrm{Ca}^{2+}$ entry mechanisms (Silinsky, 1984; Silinsky and Solsona, 1992), presumably through $G \beta \gamma$ subunits and their binding partners, syntaxin $1 \mathrm{~B}$ and SNAP25B (Blackmer et al., 2001).

Our results also indicate a close temporal correlation between changes in $\left[\mathrm{Ca}^{2+}\right]_{\mathrm{i}}$ and gonadotropin release during early and sustained GnRH actions (Stojilkovic et al., 1992b). However, the sensitivity of exocytotic machinery to $\mathrm{Ca}^{2+}$ is significantly higher during sustained agonist stimulation, suggesting that other messengers participate in control of exocytosis (Stojilkovic et al., 1990b). We have identified protein kinase $\mathrm{C}$ as a potential messenger in the sensitization of secretory vesicles to $\left[\mathrm{Ca}^{2+}\right]_{\mathrm{i}}$ (Stojilkovic et al., 1988a; 1988b; 1991), and this has been confirmed recently in experiments with single gonadotrophs (Zhu et al., 2002).

Other messengers also participate in the control of exocytosis in pituitary cells. Recently, we showed that the coupling of receptors to $\mathrm{G}_{\mathrm{i} / \mathrm{o}}$ proteins, and the subsequent silencing of pacemaker activity through activation of inwardly rectifying $\mathrm{K}^{+}$channels and inhibition of VGCCs, are not sufficient to account for inhibition of secretion by this 
particular pathway (Andric et al., 2005). Two lines of evidence support this conclusion. First, ET inhibits basal PRL secretion in picomolar concentrations, which do not affect spontaneous VGCI. Second, in cells with blocked $\mathrm{G}_{\mathrm{i} / \mathrm{o}}$ coupling, ET inhibits secretion, but not VGCI. The same study also showed that the heterotrimeric $G_{z}$ proteins provide a pathway through which ET receptors can stop secretion for a prolonged period of time without preventing pacemaking activity and VGCI-controlled cellular functions.

These results are consistent with the participation of both arms of $G_{z}$ proteins, $\alpha$ and $\beta \gamma$, in an ET-induced inhibition of PRL release downstream of VGCI. The $\mathrm{G}_{\mathrm{z}} \alpha-$ mediated attenuation of adenylyl cyclase activity in pituitary cells may account for the sustained inhibition of PRL release during ET application and the slow recovery of secretion after agonist removal. In accordance with this, it has been shown recently that the protein kinase Adependent phosphorylation of SNAP25 increases the size of slowly and rapidly releasable secretory vesicle pools without affecting the kinetics of vesicle fusion (Sakaba and Neher, 2003; Nagy et al., 2004). Thus, the $G_{z} \alpha$-mediated inhibition of adenylyl cyclase in lactotrophs could lead to depletion of the primed secretory vesicle pool. On the other hand, the rapid decrease in PRL release induced by ET at basal and elevated cAMP levels is consistent with findings in other cell types about the role of G $\beta \gamma$ subunits in control of secretion, independently of their actions on adenylyl cyclase, phospholipase $\mathrm{C}-\beta 2$, and several tyrosine kinases (Blackmer et al., 2005; Gerachshenko et al., 2005). Further studies are required to clarify the potential role of this pathway in somatostatin and dopaminecontrolled hormone release.

\section{CONCLUDING REMARKS}

Basal release of hormones from pituitary lactotrophs and somatotrophs was identified over thirty years ago, but the molecular mechanisms underlying this secretion remained largely uncharacterized. More recent studies have shown that electrical activity, and the associated extracellular $\mathrm{Ca}^{2+}$-dependent exocytosis, underlie the intrinsic secretory activity of these cells. However, excitability per se is not sufficient for effective excitation-secretion coupling as documented in spontaneously firing gonadotrophs. Extensive $\mathrm{Ca}^{2+}$ imaging studies and simultaneous electrophysiological and $\mathrm{Ca}^{2+}$ measurements revealed that AP-driven $\mathrm{Ca}^{2+}$ influx generated global high-amplitude $\mathrm{Ca}^{2+}$ transients in somatotrophs and lactotrophs but only domain, low-amplitude $\mathrm{Ca}^{2+}$ signals in gonadotrophs. However, activation of $\mathrm{Ca}^{2+}$-mobilizing GnRH-receptors in these cells leads to generation of periodic $\mathrm{Ca}^{2+}$ oscillations of similar amplitude to those observed in spontaneously active somatotrophs and lactotrophs. Spontaneous VGCI in somatotrophs and lactotrophs is not coupled to $\mathrm{Ca}^{2+}$ release from intracellular stores, whereas $\mathrm{GnRH}$-induced $\mathrm{Ca}^{2+}$ oscillations are dependent on $\mathrm{Ca}^{2+}$ mobilization from $\mathrm{InsP}_{3}$-sensitive $\mathrm{Ca}^{2+}$ stores. In somatotrophs and lactotrophs, BK channels appear to have a role in the formation of plateau-bursting electrical activity. Conversely, pituitary gonadotrophs express relatively few BK channels and spontaneously fire single spikes with a low capacity to promote $\mathrm{Ca}^{2+}$ entry. However, gonadotrophs express SK channels, which are less sensitive to $\mathrm{V}_{\mathrm{m}}$ and activation of which does not depend on VGCI but are coupled to agonist-induced $\mathrm{Ca}^{2+}$ release from intracellular stores. This provides for periodic firing of APs of higher frequency and VGCI, which sustains agonist-induced $\mathrm{Ca}^{2+}$ release and hormone secretion. Ligandgated P2X receptor-channels conduct $\mathrm{Ca}^{2+}$, but also facilitate electrical activity, and this dual action increases the basal rate of exocytosis. Finally, exocytosis is not exclusively dependent on the pattern of $\mathrm{Ca}^{2+}$ signaling, but also on other intracellular messengers, including protein kinase $\mathrm{C}$, protein kinase $A$, and $G \beta \gamma$ subunits. Gprotein coupled receptors modulate basal hormone secretion, not only by changing the pattern of VGCI and $\mathrm{Ca}^{2+}$ release from ER, but also by acting directly on the secretory pathway. 


\section{ACKNOWLEDGEMENTS}

This research was supported by the Intramural Research Program of the National Institute of Child Health and Human Development, NIH.

\section{REFERENCES}

AN SJ, ALMERS W (2004) Tracking SNARE complex formation in live endocrine cells. Science 306: 1042 1046

ANDRIC SA, ZIVADINOVIC D, GONZALEZ-IGLESIAS AE, LACHOWICZ A, TOMIC M, STOJILKOVIC SS (2005) Endothelin-induced, long lasting, and $\mathrm{Ca}^{2+}$ influx-independent blockade of intrinsic secretion in pituitary cells by $\mathrm{Gz}$ subunits. J Biol Chem 280: 26896-26903

ASHWORTH R, HINKLE PM (1996) Thyrotropinreleasing hormone-induced intracellular calcium responses in individual rat lactotrophs and thyrotrophs. Endocrinology 137: 5205-5212

BEN-JONATHAN N, HNASKO R (2001) Dopamine as a prolactin (PRL) Inhibitor. Endocr Rev 22: 724-763

BEZPROZVANNY I, WATRAS J, EHRLICH BE (1991) Bell-shaped calcium-response curves of Ins $(1,4,5) \mathrm{P} 3$ and calcium-gated channels from endoplasmic reticulum of cerebellum. Nature 351: 751-754

BLACKMER T, LARSEN EC, BARTLESON C, KOWALCHYK JA, YOON EJ, PREININGER AM, ALFORD S, HAMM HE, MARTIN TF (2005) G protein betagamma directly regulates SNARE protein fusion machinery for secretory granule exocytosis. Nat Neurosci 8: 421-425

BLACKMER T, LARSEN EC, TAKAHASHI M, MARTIN TF, ALFORD S, HAMM HE (2001) G protein betagamma subunit-mediated presynaptic inhibition: Regulation of exocytotic fusion downstream of $\mathrm{Ca}^{2+}$ entry. Science 292: 293-297

BLUET-PAJOT MT, EPELBAUM J, GOURDJI D, HAMMOND C, KORDON C (1998) Hypothalamic and hypophyseal regulation of growth hormone secretion. Cell Mol Neurobiol 18: 101-123

BONNEFONT X, MOLLARD P (2003) Electrical activity in endocrine pituitary cells in situ: A support for a multiple-function coding. FEBS Lett 548: 49-52

BRAKE AJ, WAGENBACH MJ, JULIUS D (1994) New structural motif for ligand-gated ion channels defined by an ionotropic ATP receptor. Nature 371: 519-523

CABRERA-VERA TM, VANHAUWE J, THOMAS TO, MEDKOVA M, PREININGER A, MAZZONI MR, HAMM HE (2003) Insights into G protein structure, function, and regulation. Endocr Rev 24: 765-781

CAMACHO P, LECHLEITER JD (1993) Increased frequency of calcium waves in Xenopus laevis oocytes that express a calcium-ATPase. Science 260: 226-229

CHEN ZP, KRATZMEIER M, LEVY A, MCARDLE CA, POCH A, DAY A, MUKHOPADHYAY AK, LIGHTMAN SL (1995) Evidence for a role of pituitary ATP receptors in the regulation of pituitary function. Proc Natl Acad Sci USA 92: 5219-5223

DE YOUNG GW, KEIZER J (1992) A single-pool inositol 1,4,5-trisphosphate-receptor-based model for agoniststimulated oscillations in $\mathrm{Ca}^{2+}$ concentration. Proc Natl Acad Sci USA 89: 9895-9899
DI PAOLO G, MOSKOWITZ HS, GIPSON K, WENK MR, VORONOV S, OBAYASHI M, FLAVELL $R$, FITZSIMONDS RM, RYAN TA, DE CAMILLI P (2004) Impaired PtdIns(4,5)P2 synthesis in nerve terminals produces defects in synaptic vesicle trafficking. Nature 431: 415-422

DUBINSKY JM, OXFORD GS (1984) Ionic currents in two strains of rat anterior pituitary tumor cells. J Gen Physiol 83: 309-339

FREEMAN ME, KANYICSKA B, LERANT A, NAGY G (2000) Prolactin: Structure, function, and regulation of secretion. Physiol Rev 80: 1523-1631

GERACHSHENKO T, BLACKMER T, YOON EJ, BARTLESON C, HAMM HE, ALFORD S (2005) Gbetagamma acts at the $\mathrm{C}$ terminus of SNAP-25 to mediate presynaptic inhibition. Nat Neurosci 8: 597 . 605

GILLIS KD, MOSSNER R, NEHER E (1996) Protein kinase $\mathrm{C}$ enhances exocytosis from chromaffin cells by increasing the size of the readily releasable pool of secretory granules. Neuron 16: 1209-1220

GIRALDEZ T, DE LA PENA P, GOMEZ-VARELA D, BARROS F (2002) Correlation between electrical activity and intracellular $\mathrm{Ca}^{2+}$ oscillations in $\mathrm{GH} 3$ rat anterior pituitary cells. Cell Calcium 31: 65-78

GIRARD S, CLAPHAM D (1993) Acceleration of intracellular calcium waves in xenopus oocytes by calcium influx. Science 260: 229-232

GRISHANIN RN, KOWALCHYK JA, KLENCHIN VA, ANN K, EARLES CA, CHAPMAN ER, GERONA RR, MARTIN TF (2004) CAPS acts at a prefusion step in dense-core vesicle exocytosis as a PIP2 binding protein. Neuron 43: 551-562

HAUG TM, HAFTING T, SAND O (2004) Inhibition of BK channels contributes to the second phase of the response to TRH in clonal rat anterior pituitary cells. Acta Physiol Scand 180: 347-357

HE ML, GONZALEZ-IGLESIAS AE, STOJILKOVIC SS (2003) Role of nucleotide P2 receptors in calcium signaling and prolactin release in pituitary lactotrophs. J Biol Chem 278: 46270-46277

HE ML, GONZALEZ-IGLESIAS AE, TOMIC M, STOJILKOVIC SS (2005) Release and extracellular metabolism of ATP by ecto-nucleotidase eNTPDase 13 in hypothalamic and pituitary cells. Purinergic Signalling 1: 135-144

IIDA T, STOJILKOVIC SS, IZUMI S, CATT KJ (1991) Spontaneous and agonist-induced calcium oscillations in pituitary gonadotrophs. Mol Endocrinol 5: 949-958

KAFTAN EJ, XU T, ABERCROMBIE RF, HILLE B (2000) Mitochondria shape hormonally induced cytoplasmic calcium oscillations and modulate exocytosis. J Biol Chem 275: 25465-25470

KEHL SJ, WONG K (1996) Large-conductance calciumactivated potassium channels of cultured rat melanotrophs. J Membr Biol 150: 219-230

KEIZER J, LI YX, STOJILKOVIC S, RINZEL J (1995) InsP3-induced $\mathrm{Ca}^{2+}$ excitability of the endoplasmic reticulum. Mol Biol Cell 6: 945-951

KORN SJ, BOLDEN A, HORN R (1991) Control of action potentials and $\mathrm{Ca}^{2+}$ influx by the $\mathrm{Ca}^{(2+)}$-dependent chloride current in mouse pituitary cells. J Physiol 439: 423-437

KOSHIMIZU T, TOMIC M, KOSHIMIZU M, STOJILKOVIC SS (1998a) Identification of amino acid residues contributing to desensitization of the P2X2 receptor channel. J Biol Chem 273: 12853-12857

KOSHIMIZU T, TOMIC M, VAN GOOR F, STOJILKOVIC SS (1998b) Functional role of alternative splicing in pituitary $\mathrm{P} 2 \mathrm{X} 2$ receptor-channel 
activation and desensitization. Mol Endocrinol 12: 901913

KOSHIMIZU TA, TOMIC M, WONG AO, ZIVADINOVIC D, STOJILKOVIC SS (2000) Characterization of purinergic receptors and receptorchannels expressed in anterior pituitary cells. Endocrinology 141: 4091-4099

KRSMANOVIC LZ, STOJIKOVIC SS, CATT KJ (1996) Pulsatile gonadotropin-releasing hormone release and its regulation. Trends Endocrinol Metab 7: 56-59

KUKULJAN M, ROJAS E, CATT KJ, STOJILKOVIC SS (1994) Membrane potential regulates inositol 1,4,5trisphosphate-controlled cytoplasmic $\mathrm{Ca}^{2+}$ oscillations in pituitary gonadotrophs. J Biol Chem 269: 4860-4865

KUKULJAN M, STOJILKOVIC SS, ROJAS E, CATT KJ (1992) Apamin-sensitive potassium channels mediate agonist-induced oscillations of membrane potential in pituitary gonadotrophs. FEBS Lett 301: 19-22

KUKULJAN M, VERGARA L, STOJILKOVIC SS (1997) Modulation of the kinetics of inositol 1,4,5trisphosphate-induced $\left[\mathrm{Ca}^{2+}\right] \mathrm{i}$ oscillations by calcium entry in pituitary gonadotrophs. Biophys J 72: 698-707

KWIECIEN R, HAMMOND C (1998) Differential management of $\mathrm{Ca}^{2+}$ oscillations by anterior pituitary cells: A comparative overview. Neuroendocrinology 68: $135-151$

KWIECIEN R, ROBERT C, CANNON R, VIGUES S, ARNOUX A, KORDON C, HAMMOND C (1998) Endogenous pacemaker activity of rat tumour somatotrophs. J Physiol 508 (Pt 3): 883-905

LANG DG, RITCHIE AK (1990) Tetraethylammonium blockade of apamin-sensitive and insensitive $\mathrm{Ca}^{2(+)}$ activated $\mathrm{K}^{+}$channels in a pituitary cell line. $\mathrm{J}$ Physiol 425: $117-132$

LECHLEITER JD, CLAPHAM DE (1992) Molecular mechanisms of intracellular calcium excitability in $\mathrm{X}$. laevis oocytes. Cell 69: 283-294

LEWIS DL, GOODMAN MB, ST JOHN PA, BARKER JL (1988) Calcium currents and fura-2 signals in fluorescence-activated cell sorted lactotrophs and somatotrophs of rat anterior pituitary. Endocrinology 123: 611-621

LI YX, RINZEL J, VERGARA L, STOJILKOVIC SS (1995) Spontaneous electrical and calcium oscillations in unstimulated pituitary gonadotrophs. Biophys J 69: 785-795

LI YX, STOJILKOVIC SS, KEIZER J, RINZEL J (1997) Sensing and refilling calcium stores in an excitable cell. Biophys J 72: 1080-1091

LIN MW, YANG SR, HUANG MH, WU SN (2004) Stimulatory actions of caffeic acid phenethyl ester, a known inhibitor of NF-kappaB activation, on $\mathrm{Ca}^{2+}$ activated $\mathrm{K}^{+}$current in pituitary $\mathrm{GH} 3$ cells. J Biol Chem 279: 26885-26892

MANSVELDER HD, KITS KS (1998) The relation of exocytosis and rapid endocytosis to calcium entry evoked by short repetitive depolarizing pulses in rat melanotropic cells. J Neurosci 18: 81-92

MARTIN TF (2003) Tuning exocytosis for speed: Fast and slow modes. Biochim Biophys Acta 1641: 157-165

MASON WT, RAWLINGS SR (1988) Whole-cell recordings of ionic currents in bovine somatotrophs and their involvement in growth hormone secretion. J Physiol 405: 577-593

MAYO KE, GODFREY PA, SUHR ST, KULIK DJ, RAHAL JO (1995) Growth hormone-releasing hormone: Synthesis and signaling. Recent Prog Horm Res 50: 35-73

MIRANDA P, DE LA PENA P, GOMEZ-VARELA D BARROS F (2003) Role of BK potassium channels shaping action potentials and the associated $\left[\mathrm{Ca}^{(2+)}\right](\mathrm{i})$ oscillations in $\mathrm{GH}(3)$ rat anterior pituitary cells Neuroendocrinology 77: 162-176

MOLLARD P, THELER JM, GUERINEAU N, VACHER P, CHIAVAROLI C, SCHLEGEL W (1994) Cytosolic $\mathrm{Ca}^{2+}$ of excitable pituitary cells at resting potentials is controlled by steady state $\mathrm{Ca}^{2+}$ currents sensitive to dihydropyridines. J Biol Chem 269: 25158-25164

NAGY G, REIM K, MATTI U, BROSE N, BINZ T, RETTIG J, NEHER E, SORENSEN JB (2004) Regulation of releasable vesicle pool sizes by protein kinase A-dependent phosphorylation of SNAP-25. Neuron 41: 417-429

NORTH RA (2002) Molecular physiology of P2X receptors. Physiol Rev 82: 1013-1067

OOI GT, TAWADROS N, ESCALONA RM (2004) Pituitary cell lines and their endocrine applications. Mol Cell Endocrinol 228: 1-21

REES DA, SCANLON MF, HAM J (2003) Novel insights into how purines regulate pituitary cell function. Clin Sci (Lond) 104: 467-481

RETTIG J, NEHER E (2002) Emerging roles of presynaptic proteins in $\mathrm{Ca}^{++}$-triggered exocytosis. Science 298: 781-785

RITCHIE AK (1987a) Thyrotropin-releasing hormone stimulates a calcium-activated potassium current in a rat anterior pituitary cell line. J Physiol 385: 611-625

RITCHIE AK (1987b) Two distinct calcium-activated potassium currents in a rat anterior pituitary cell line. $\mathrm{J}$ Physiol 385: 591-609

SAKABA T, NEHER E (2003) Direct modulation of synaptic vesicle priming by GABA(B) receptor activation at a glutamatergic synapse. Nature 424: 775778

SANKARANARAYANAN S, SIMASKO SM (1996) Characterization of an M-like current modulated by thyrotropin-releasing hormone in normal rat lactotrophs. J Neurosci 16: 1668-1678

SCHLEGEL W, WINIGER BP, MOLLARD P, VACHER P, WUARIN F, ZAHND GR, WOLLHEIM CB, DUFY B (1987) Oscillations of cytosolic $\mathrm{Ca}^{2+}$ in pituitary cells due to action potentials. Nature 329: 719-721

SHIPSTON MJ, KELLY JS, ANTONI FA (1996) Glucocorticoids block protein kinase A inhibition of calcium-activated potassium channels. J Biol Chem 271: $9197-9200$

SILINSKY EM (1984) On the mechanism by which adenosine receptor activation inhibits the release of acetylcholine from motor nerve endings. J Physiol 346: 243-256

SILINSKY EM, SOLSONA CS (1992) Calcium currents at motor nerve endings: Absence of effects of adenosine receptor agonists in the frog. $\mathrm{J}$ Physiol 457: 315-328

SIMASKO SM, WEILAND GA, OSWALD RE (1988) Pharmacological characterization of two calcium currents in GH3 cells. Am J Physiol 254: E328-336

STOJILKOVIC SS, CATT KJ (1992) Calcium oscillations in anterior pituitary cells. Endocr Rev 13: 256-280

STOJILKOVIC SS, CATT KJ (1995) Novel aspects of GnRH-induced intracellular signaling and secretion in pituitary gonadotrophs. J Neuroendocrinol 7: 739-757

STOJILKOVIC SS, CHANG JP, IZUMI S, TASAKA K, CATT KJ (1988a) Mechanisms of secretory responses to gonadotropin-releasing hormone and phorbol esters in cultured pituitary cells. Participation of protein kinase $\mathrm{C}$ and extracellular calcium mobilization. J Biol Chem 263: 17301-17306

STOJILKOVIC SS, CHANG JP, NGO D, CATT KJ (1988b) Evidence for a role of protein kinase $\mathrm{C}$ in luteinizing hormone synthesis and secretion. Impaired 
responses to gonadotropin-releasing hormone in protein kinase C-depleted pituitary cells. J Biol Chem 263: 17307-17311

STOJILKOVIC SS, IIDA T, MERELLI F, TORSELLO A, KRSMANOVIC LZ, CATT KJ (1991) Interactions between calcium and protein kinase $\mathrm{C}$ in the control of signaling and secretion in pituitary gonadotrophs. J Biol Chem 266: 10377-10384

STOJILKOVIC SS, IIDA T, VIRMANI MA, IZUMI S, ROJAS E, CATT KJ (1990a) Dependence of hormone secretion on activation-inactivation kinetics of voltagesensitive $\mathrm{Ca}^{2+}$ channels in pituitary gonadotrophs. Proc Natl Acad Sci USA 87: 8855-8859

STOJILKOVIC SS, KOSHIMIZU T (2001) Signaling by extracellular nucleotides in anterior pituitary cells. Trends Endocrinol Metab 12: 218-225

STOJILKOVIC SS, KUKULJAN M, IIDA T, ROJAS E, CATT KJ (1992a) Integration of cytoplasmic calcium and membrane potential oscillations maintains calcium signaling in pituitary gonadotrophs. Proc Natl Acad Sci USA 89: 4081-4085

STOJILKOVIC SS, KUKULJAN M, TOMIC M, ROJAS E, CATT KJ (1993) Mechanism of agonist-induced $\left[\mathrm{Ca}^{2+}\right] \mathrm{i}$ oscillations in pituitary gonadotrophs. J Biol Chem 268: 7713-7720

STOJILKOVIC SS, ROJAS E, STUTZIN A, IZUMI S, CATT KJ (1989) Desensitization of pituitary gonadotropin secretion by agonist-induced inactivation of voltage-sensitive calcium channels. J Biol Chem 264: 10939-10942

STOJILKOVIC SS, STUTZIN A, IZUMI S, DUFOUR S, TORSELLO A, VIRMANI MA, ROJAS E, CATT KJ (1990b) Generation and amplification of the cytosolic calcium signal during secretory responses to gonadotropin-releasing hormone. New Biol 2: 272-283

STOJILKOVIC SS, TOMIC M, KUKULJAN M, CATT KJ (1994) Control of calcium spiking frequency in pituitary gonadotrophs by a single-pool cytoplasmic oscillator. Mol Pharmacol 45: 1013-1021

STOJILKOVIC SS, TORSELLO A, IIDA T, ROJAS E, CATT KJ (1992b) Calcium signaling and secretory responses in agonist-stimulated pituitary gonadotrophs. J Steroid Biochem Mol Biol 41: 453-467

STOJILKOVIC SS, ZEMKOVA H, VAN GOOR F (2005) Biophysical basis of pituitary cell type-specific $\mathrm{Ca}^{2+}$ signaling-secretion coupling. Trends Endocrinol Metab 16: $152-159$

STUTZIN A, STOJILKOVIC SS, CATT KJ, ROJAS E (1989) Characteristics of two types of calcium channels in rat pituitary gonadotrophs. Am J Physiol 257: C865874

SUN Y, LU X, GERSHENGORN MC (2003) Thyrotropinreleasing hormone receptors - Similarities and differences. J Mol Endocrinol 30: 87-97

TOMIC M, ANDRIC SA, STOJILKOVIC SS (2003) Dependence of prolactin release on coupling between $\mathrm{Ca}^{(2+)}$ mobilization and voltage-gated $\mathrm{Ca}^{(2+)}$ influx pathways in rat lactotrophs. Endocrine 20: 45-52

TOMIC M, CESNAJAJ M, CATT KJ, STOJILKOVIC SS (1994) Developmental and physiological aspects of $\mathrm{Ca}^{2+}$ signaling in agonist-stimulated pituitary gonadotrophs. Endocrinology 135: 1762-1771

TOMIC M, JOBIN RM, VERGARA LA, STOJILKOVIC SS (1996) Expression of purinergic receptor channels and their role in calcium signaling and hormone release in pituitary gonadotrophs. Integration of P2 channels in plasma membrane- and endoplasmic reticulum-derived calcium oscillations. J Biol Chem 271: 21200-21208

TOMIC M, KOSHIMIZU T, YUAN D, ANDRIC SA, ZIVADINOVIC D, STOJILKOVIC SS (1999a)
Characterization of a plasma membrane calcium oscillator in rat pituitary somatotrophs. J Biol Chem 274: 35693-35702

TOMIC M, VAN GOOR F, HE ML, ZIVADINOVIC D, STOJILKOVIC SS (2002) $\mathrm{Ca}^{(2+)}$-mobilizing endothelin-A receptors inhibit voltage-gated $\mathrm{Ca}^{(2+)}$ influx through $\mathrm{G}_{(\mathrm{i} / \mathrm{o})}$ signaling pathway in pituitary lactotrophs. Mol Pharmacol 61: 1329-1339

TOMIC M, ZIVADINOVIC D, VAN GOOR F, YUAN D, KOSHIMIZU T, STOJILKOVIC SS (1999b) Expression of $\mathrm{Ca}^{(2+)}$-mobilizing endothelin(A) receptors and their role in the control of $\mathrm{Ca}^{(2+)}$ influx and growth hormone secretion in pituitary somatotrophs. J Neurosci 19: 7721-7731

TSE A, HILLE B (1992) GnRH-induced $\mathrm{Ca}^{2+}$ oscillations and rhythmic hyperpolarizations of pituitary gonadotropes. Science 255: 462-464

TSE A, HILLE B (1993) Role of voltage-gated $\mathrm{Na}^{+}$and $\mathrm{Ca}^{2+}$ channels in gonadotropin-releasing hormoneinduced membrane potential changes in identified rat gonadotropes. Endocrinology 132: 1475-1481

TSE A, TSE FW, ALMERS W, HILLE B (1993) Rhythmic exocytosis stimulated by GnRH-induced calcium oscillations in rat gonadotropes. Science 260: 82-84

TSE A, TSE FW, HILLE B (1994a) Calcium homeostasis in identified rat gonadotrophs. J Physiol 477 (Pt 3): 511-525

TSE FW, TSE A, HILLE B (1994b) Cyclic Ca ${ }^{2+}$ changes in intracellular stores of gonadotropes during gonadotropin-releasing hormone-stimulated $\mathrm{Ca}^{2+}$ oscillations. Proc Natl Acad Sci USA 91: 9750-9754

TSE FW, TSE A, HILLE B, HORSTMANN H, ALMERS W (1997) Local $\mathrm{Ca}^{2+}$ release from internal stores controls exocytosis in pituitary gonadotrophs. Neuron 18: $121-132$

TSUBOI T, MCMAHON HT, RUTTER GA (2004) Mechanisms of dense core vesicle recapture following "kiss and run" ("cavicapture") exocytosis in insulinsecreting cells. J Biol Chem 279: 47115-47124

VAN GOOR F, LI YX, STOJILKOVIC SS (2001a) Paradoxical role of large-conductance calciumactivated $\mathrm{K}^{+}(\mathrm{BK})$ channels in controlling action potential-driven $\mathrm{Ca}^{2+}$ entry in anterior pituitary cells. $\mathrm{J}$ Neurosci 21: 5902-5915

VAN GOOR F, ZIVADINOVIC D, MARTINEZFUENTES AJ, STOJILKOVIC SS (2001b) Dependence of pituitary hormone secretion on the pattern of spontaneous voltage-gated calcium influx. Cell type-specific action potential secretion coupling. J Biol Chem 276: 33840-33846

VAN GOOR F, ZIVADINOVIC D, STOJILKOVIC SS (2001c) Differential expression of ionic channels in rat anterior pituitary cells. Mol Endocrinol 15: 1222-1236

VERGARA L, ROJAS E, STOJILKOVIC SS (1997) A novel calcium-activated apamin-insensitive potassium current in pituitary gonadotrophs. Endocrinology 138: 2658-2664

VERGARA LA, STOJILKOVIC SS, ROJAS E (1995) GnRH-induced cytosolic calcium oscillations in pituitary gonadotrophs: Phase resetting by membrane depolarization. Biophys J 69: 1606-1614

YANG Y, UDAYASANKAR S, DUNNING J, CHEN P, GILLIS KD (2002) A highly $\mathrm{Ca}^{2+}$-sensitive pool of vesicles is regulated by protein kinase $\mathrm{C}$ in adrenal chromaffin cells. Proc Natl Acad Sci USA 99: 1706017065

ZEMKOVA H, BALIK A, JIANG, Y, KRETSCHMANNOVA K, STOJILKOVIC SS (2006) Roles of purinergic $\mathrm{P} 2 \mathrm{X}$ receptors as pacemaking chanenls and modulators of calcium-mobilizing 
pathway in pituitary gonadotrophs. Mol Endocrinol 20: 1423-1436

ZEMKOVA H, BALIK A, KRETSCHMANNOVA K, MAZNA P, STOJILKOVIC SS (2004) Recovery of Ins $(1,4,5)$-trisphosphate-dependent calcium signaling in neonatal gonadotrophs. Cell Calcium 36: 89-97

ZEMKOVA H, VANECEK J (2000) Differences in gonadotropin-releasing hormone-induced calcium signaling between melatonin-sensitive and melatonininsensitive neonatal rat gonadotrophs. Endocrinology 141: $1017-1026$

ZHENG L, PAIK WY, CESNJAJ M, BALLA T, TOMIC M, CATT KJ, STOJILKOVIC SS (1995) Effects of the phospholipase-C inhibitor, U73122, on signaling and secretion in pituitary gonadotrophs. Endocrinology 136: $1079-1088$

ZHU H, HILLE B, XU T (2002) Sensitization of regulated exocytosis by protein kinase C. Proc Natl Acad Sci USA 99: 17055-17059

ZIMBER MP, SIMASKO SM (2000) Recruitment of calcium from intracellular stores does not occur during the expression of large spontaneous calcium oscillations in $\mathrm{GH}(3)$ cells and lactotropic cells in primary culture. Neuroendocrinology 72: 242-251

ZIMMERMANN H (2000) Extracellular metabolism of ATP and other nucleotides. Naunyn Schmiedebergs Arch Pharmacol 362: 299-309 
